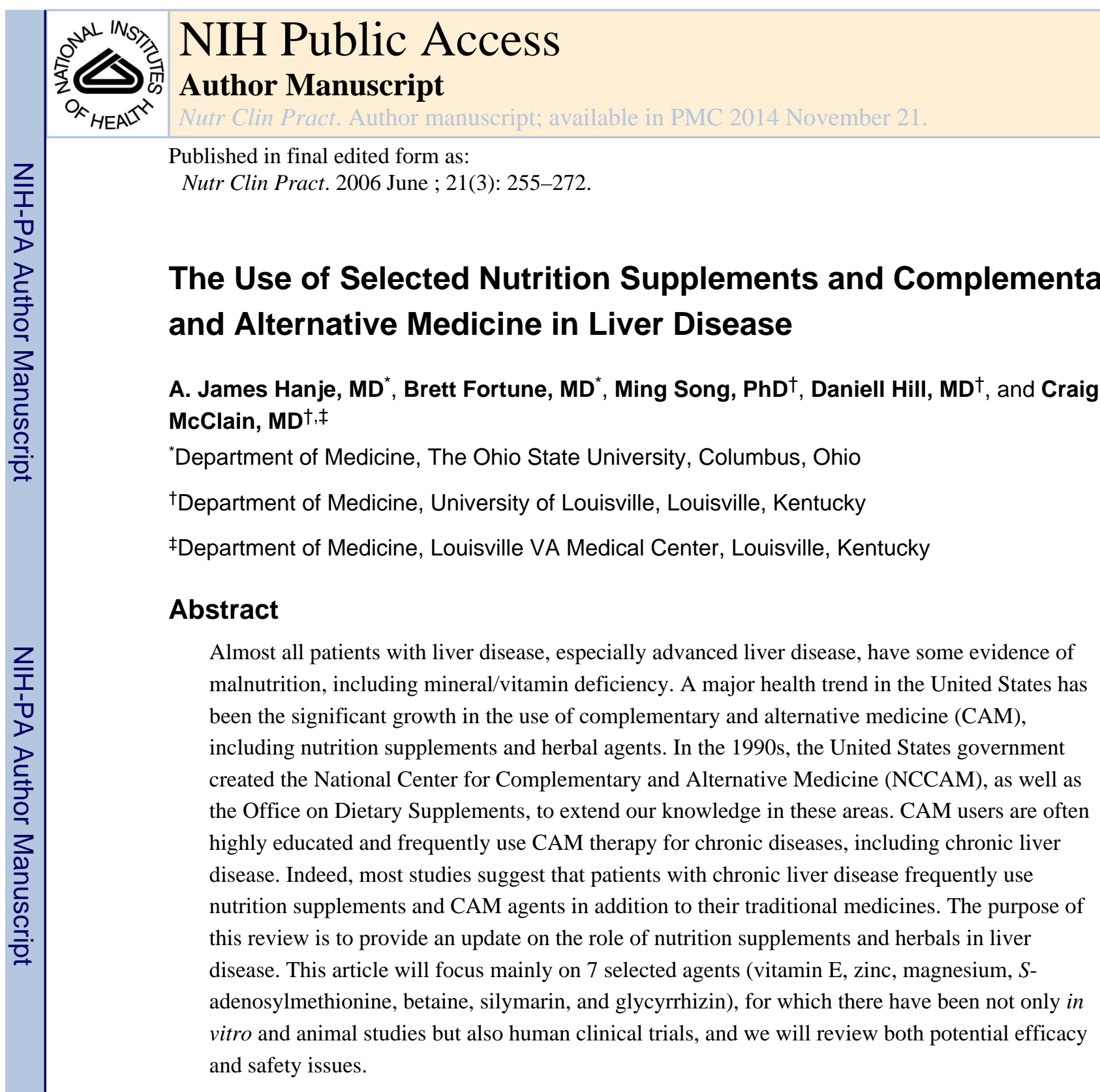

\begin{abstract}
Malnutrition, including individual nutrient deficiencies, is regularly observed in liver disease, especially in more severe forms of chronic liver disease. ${ }^{1}$ Probably the most extensive studies of nutrition status in patients with liver disease are in patients with alcoholic liver disease (ALD), exemplified by 2 large studies in the Veterans Health Administra tion (VA) Cooperative Studies Program dealing with patients having alcoholic hepatitis. ${ }^{2-6}$ Virtually every patient with alcoholic hepatitis in these studies had some degree of malnutrition, ${ }^{4}$ the severity of which correlated with the development of serious complications such as encephalopathy, ascites, and hepatorenal syndrome. ${ }^{2}$ Malnutrition is also well documented in non-alcohol-related liver diseases. Indeed, there have been several major studies comparing patients with ALD to those with nonalcoholic (especially viral)
\end{abstract}

\footnotetext{
Copyright () 2006 American Society for Parenteral and Enteral Nutrition

Correspondence: Craig J. McClain, MD, Department of Internal Medicine, Professor of Internal Medicine, Pharmacology and Toxicology, University of Louisville Medical Center, 550 S Jackson St, ACB 3rd Floor, Louisville, KY 40292. Electronic mail may be sent to craig.mcclain@ louisville.edu..
} 
induced liver diseases. ${ }^{1,7,8}$ Although the problems of malnutrition in liver disease varied somewhat between the different studies, there was no significant difference in the occurrence of malnutrition between alcohol and non-alcohol-related causes. Mechanisms for malnutrition/ nutrient deficiency are varied and include factors such as poor intake, impaired gastric emptying, decreased absorption, increased fecal and urinary losses, and cytokine effects, to name only a few (as reviewed in McClain et $\mathrm{al}^{1}$ ).

A major health trend in the United States has been the significant growth in the use of complementary and alternative medicine (CAM), including nutrition supplements and herbal agents. ${ }^{9}$ Studies by Eisenberg and colleagues ${ }^{10,11}$ document the high prevalence of CAM use in the United States and the large out-of-pocket dollars spent on CAM. In the 1990s, the United States government created the National Center for Complementary and Alternative Medicine (NCCAM), as well as the Office on Dietary Supplements, to extend our knowledge in these areas. ${ }^{12}$ There are updated versions of Physician's Desk Reference for both herbal therapies and dietary supplements to help educate health-care providers on this topic. CAM users are often highly educated and frequently use CAM therapy for chronic diseases. Thus, it is not surprising that CAM is widely used in patients with chronic liver diseases. The National Institutes of Health (NIH) has sponsored a variety of symposia relating to CAM and liver disease over the past decade. There have been requests for applications from the NIH to study the potential therapeutic benefits of various types of CAM use (eg, milk thistle), or supplements (eg,vitamin E), in liver disease. Many of these studies are ongoing.

The purpose of this review is to provide an update on the role of nutrition supplements and herbals in liver disease. Through the on-line MEDLINE Library (1966-2006), we used several headings and key words, including zinc, vitamin E, magnesium, CAM, herbals, Sadenosylmethionine, glycyrrhizin, licorice root, milk thistle, silymarin, TJ-9, Phyllan-thus amarus, Picrorrhiza kurroa, Compound 861, CH 100, betaine, EH0202, EO-50, garlic, gingko, ginseng, green tea, rhei rhizome, shosaikoto, liver disease, hepatitis, cirrhosis, hepatotoxicity, black cohosh, kava, and fatty liver disease to review the relevant literature. Only articles that were translated or published in English were included. This article will focus mainly on 7 selected agents (vita-min E, zinc, magnesium, S-adenosylmethionine, betaine, silymarin, and glycyrrhizin) in which there have been in vitro and animal studies and human clinical trials, and we will review both potential efficacy and safety issues.

\section{Vitamin E}

\section{Vitamin E in Nonalcoholic Steatohepatitis}

Pathophysiology-In examining the potential therapeutic benefits of vitamin $\mathrm{E}$ in both alcoholic and nonalcoholic chronic liver disease, it is important to understand potential mechanisms of action. Tumor necrosis factor $a(\mathrm{TNF}-a)$ is a proinflammatory cytokine important in the pathogenesis of nonalcoholic and ALD, ${ }^{13,14}$ and nuclear factor kappa B $(\mathrm{NF} \kappa \mathrm{B})$ is a transcription factor for TNF- $a$, as well as other proinflammatory cytokines. ${ }^{13-17}$ Previous in vitro studies demonstrated increased binding activity of NF $\kappa \mathrm{B}$ in human monocytes treated with ethanol, and subsequent studies showed that patients with alcoholic hepatitis demonstrate increased monocyte $\mathrm{NF} \kappa \mathrm{B}$ activation and increased 
production of TNF- $\alpha .{ }^{14,18}$ Furthermore, in vitro vitamin $\mathrm{E}$ treatment of monocytes from patients with alcoholic hepatitis decreased NF $\kappa \mathrm{B}$ activation and effectively inhibited TNF- $\alpha$ production. ${ }^{19}$ In nonalcoholic fatty liver disease (NAFLD), there is also emerging evidence to suggest a role for TNF- $\alpha$ and $\mathrm{NF} \kappa \mathrm{B}$, although their exact roles have yet to be elucidated. Oxidative stress has been postulated as an essential step in the progression of NAFLD, a second "hit" that pre-disposes hepatocytes to undergo apoptosis. ${ }^{13,20}$ Patients with nonalcoholic steatohepatitis (NASH) have been shown to have increased serum levels of TNF- $a{ }^{21-23} \mathrm{NF} \kappa \mathrm{B}$ activation has also been shown to be enhanced by oxidative stress. A recent study highlighted the importance of $\mathrm{NF} \kappa \mathrm{B}$ activation in the pathogenesis of NAFLD/ $\mathrm{NASH}$ by demonstrating increased early activation of $\mathrm{NF} \kappa \mathrm{B}$ in mice with induced steatohepatitis. ${ }^{24} \mathrm{NF} \kappa \mathrm{B}$ also plays an essential role in the activation of stellate cells, a key step in collagen production and hepatic fibrogenesis. Vitamin $\mathrm{E}$ has been shown to block in vitro activation of stellate cells, in part by decreasing $\mathrm{NF} \kappa \mathrm{B}$ activity. ${ }^{25}$ Plasma transforming growth factor- $\beta 1$ (TGF- $\beta 1$ ) is a profibrotic cytokine found to be elevated in patients with non-ALD, specifically, NASH. Expression of TGF- $\beta 1$ is increased in animal models of hepatic fibrosis, and in studies performed in rats with carbon tetrachloride $\left(\mathrm{CCl}_{4}\right)$-induced liver fibrosis, treatment with vitamin $\mathrm{E}$ decreased levels of TGF- $\beta$ and improved liver injury and fibrosis. ${ }^{26-28}$

Therapeutic Trials-In a limited number of mostly pilot studies done in humans, the effects of vitamin $\mathrm{E}$ in patients with NAFLD and NASH are mixed. There are some data to suggest histologic and biochemical improvement in patients with NASH treated with vitamin E, although this is currently an area of ongoing research.

One of the most commonly cited studies involving vitamin E and NASH involved an openlabel pilot study of 11 children with NASH treated with vita-min E. Patients were treated with dietary instruction and high-dose vitamin E (between 400 and 1200 IU/day) for 4-10 months. Alanine aminotransferase (ALT) levels were measured during treatment and for a mean period of 5 months afterward. Vitamin E dose was increased monthly from $400 \mathrm{IU} /$ day to a maximum of $1200 \mathrm{IU} / \mathrm{day}$ if ALT levels remained elevated. Mean body mass index (BMI) did not change during the course of the study. Five of 11 patients showed significant improvement in ALT levels with the lowest dose (400 IU/day), 4 patients improved with $800 \mathrm{IU} /$ day, and 2 patients treated with $1200 \mathrm{IU} /$ day showed improvement in ALT levels. Histology was not obtained. ${ }^{29}$

Another randomized controlled trial (RCT) studied 28 children with NASH treated with vitamin E. Groups were randomized to dietary instruction or dietary instruction with vitamin $\mathrm{E}$ (400 IU/day $\times 2$ months; $100 \mathrm{IU} /$ day $\times 3$ months) and followed for 5 months. Vitamin $\mathrm{E}$ was shown to be effective in reducing and normalizing transaminases in children with NASH (no effect on ultrasound liver brightness was noted). ${ }^{30}$

In adult studies, the results are more mixed. A nonrandomized, non-placebo-controlled pilot study of 22 Japanese patients examined patients with NAFLD and NASH treated with vitamin E. Patients were treated with dietary instruction for 6 months, followed by vitamin $\mathrm{E}$ (300 IU/day) for 1 year. The authors found that TGF- $\beta 1$ levels were significantly higher in the patients with NASH when compared with patients with NAFLD or healthy subjects. 
Elevated TGF- $\beta 1$ in patients with NASH improved after 1 year of vitamin E treatment and correlated with improvements in ALT levels. In the patients with NASH, 5 of 9 also showed histologic improvement with decreased inflammation and fibrosis after treatment with vitamin E. $^{31}$

We evaluated 16 adults with NASH treated with vitamin E. Patients were treated with either dietary instruction alone or dietary instruction and $800 \mathrm{IU} /$ day of vitamin $\mathrm{E}$ for 12 weeks. Both groups demonstrated an improvement in BMI. Both groups also demonstrated a significant improvement in ALT and aspartate aminotransferase (AST); however, subgroup analysis showed no further benefit in the patients treated with vitamin $\mathrm{E}$ and dietary instruction when compared with the group receiving dietary instruction alone. ${ }^{21}$ Weight loss is known to decrease oxidative stress and appeared to be more important than vitamin $\mathrm{E}$ in improving liver enzymes. Another RCT looked at 20 adults with NASH treated with vitamin E or vitamin E plus pioglitazone. Patients were treated with 400 IU/day of vitamin E for 6 months with or without pioglita-zone ( $30 \mathrm{mg} /$ day). Both groups showed a significant improvement in degree of steatosis, although the vitamin E plus pioglitazone group showed a greater improvement in liver histology. ${ }^{32}$

\section{Vitamin E in ALD}

In animal models of ethanol-induced liver disease, treatment with vitamin $\mathrm{E}$ has been shown to improve liver histology and decrease CYP 2E1 activity. ${ }^{33}$ In human subjects, the studies that have been done to date have produced no conclusive evidence that vitamin $\mathrm{E}$ is effective in the treatment of ALD. A small European RCT evaluated alcoholic patients treated with an antioxidant cocktail of vitamin E, vitamin C, beta carotene, and selenium. Patients were initially admitted to the hospital for detoxification and randomized to receive either placebo or the antioxidant cocktail. After 7 days of therapy, there was no significant difference in levels of conjugated linoleic acid, used as a marker of free radical activity, or AST between the 2 groups. ${ }^{34}$ A large RCT looked at 67 patients with decompensated alcoholic cirrhosis treated with vitamin E. All patients were ambulatory and advised to abstain from alcohol. Patients were treated with $500 \mathrm{IU} /$ day of vitamin E for 1 year. At the end of 1 year, there was no significant improvement seen in liver function tests, hospitalization rates, or overall mortality when compared with placebo. ${ }^{35}$

A recent RCT studied 51 patients with mild to moderate alcoholic hepatitis treated with vitamin E. All patients were advised to abstain from alcohol. Patients were treated with 1000 IU/day of vitamin $\mathrm{E}$ for 1 year. There were no significant differences in biochemical markers (serum aminotransfereases, bilirubin, albumin, prothrombin time, or creatinine) or overall mortality between the treatment group and placebo group. This study also measured $\mathrm{NF} \kappa \mathrm{B}$ levels in both groups. In the 9 patients (6 in placebo, 3 in treatment) who resumed drinking, $\mathrm{NF} \kappa \mathrm{B}$ binding activity remained high, and no significant difference was found between those patients taking vita-min $\mathrm{E}$ or placebo. In the patients who remained abstinent, $\mathrm{NF} \kappa \mathrm{B}$ binding activity decreased after cessation of alcohol. There was no significant difference between the decrease in $\mathrm{NF} \kappa \mathrm{B}$ activity seen in the treatment and placebo groups. ${ }^{36}$ Thus, it appeared that continued alcohol intake was the most critical factor related to ongoing inflammation/ injury.

Nutr Clin Pract. Author manuscript; available in PMC 2014 November 21. 


\section{Vitamin E and Viral Hepatitis \\ Pathophysiology}

In addition to the well-accepted treatment combination of ribavirin and interferon (IFN)- $a$ for the treatment of chronic hepatitis $\mathrm{C}$, a number of studies have looked at antioxidant therapy in hopes of improving response rates. It is thought that chronic infection with the virus increases oxidative stress within the liver, a process that may be counteracted with the addition of antioxidants. Surrogate markers of oxidative stress have been found to increase in patients with chronic hepatitis $\mathrm{C}$, lending support to this hypothesis. ${ }^{37-39}$ Our group has preliminary data suggesting that 4 hydroxynonenal, a product of oxidative stress and lipid peroxidation, interferes with normal interferon signaling by inhibiting the STAT pathway. Oxidative stress has also been shown to cause enhanced activation of stellate cells and hepatic fibrogenesis in patients with chronic hepatitis $\mathrm{C}$, a process that was inhibited by 8 weeks of treatment with high dose vitamin E (1200 IU/day). ${ }^{40}$

\section{Therapeutic Trials}

A few small studies have shown a therapeutic benefit of vitamin $\mathrm{E}$ treatment in patients with chronic hepatitis C. A non-randomized trial studied 17 patients treated with vitamin E (500 $\mathrm{mg}$ /day) for 3 months. A serum marker of oxidative stress, thioredoxin (TRX), as well as ALT and AST levels, were measured before, during, and after treatment. Patients with the highest elevations in pretreatment ALT (ALT > $70 \mathrm{IU} / \mathrm{L}$ ) showed a significant reduction in ALT levels and a reduction in TRX levels that was not statistically significant. Patients with only mild elevations in pretreatment ALT (ALT < 70 IU/L) showed no improvement in ALT levels but a significant reduction in TRX levels. ${ }^{41}$

A study of 23 patients investigated nonresponders to INF- $\alpha$ and treated them with a total of $800 \mathrm{IU} /$ day of vitamin E for 12 weeks. Eleven of 23 patients showed a significant reduction in ALT and AST when compared with pretreatment levels. These biochemical improvements relapsed rapidly after discontinuation of therapy and were reproduced upon retreatment with vitamin $\mathrm{E}$ after a 6-month follow-up. ${ }^{42}$

A third RCT looked at 24 INF- $a$ naïve patients with hepatitis C treated with either INF- $a$ mono-therapy (4.5 million units, 3 times a week; group A), INF- $\alpha$ and antioxidants ( $N$ acetylcysteine plussodium selenite but excluding vitamin E; group B), and INF- $a$, antioxidants, and vitamin E at a dose of $544 \mathrm{IU} /$ day (group C). All 3 groups of patients were treated for a total of 24 weeks and then followed for 6 months after treatment. The results showed patients treated with vitamin E (group C) had a better chance of obtaining an end-oftreatment response (ETR, defined as normalization of ALT and negative hepatitis $\mathrm{C}$ virus [HCV] RNA) and demonstrated an overall reduction in viral load $v s$ non-vitamin-E-treated patients (groups A and B), although these results did not attain statistical significance. No significant histologic changes were seen between any of the 3 groups. Of the 11 patients that initially responded (3 in group A, 2 in group B, and 6 in group C), 7 relapsed within 6 months of discontinuation of therapy ( 4 of 6 patients in group $\mathrm{C}$ ). ${ }^{43}$

These results contrast with the findings of 2 other reports that found no benefit with the addition of vitamin E to INF- $a$-based regimens. The first was a multicenter European RCT 
involving 120 patients with chronic $\mathrm{HCV}$, previously unresponsive to INF- $a$ monotherapy. Patients were randomized to receive either weight-based INF- $a$ (3-6 million units, 3 times a week) or INF- $a$ and antioxidant therapy consisting of $N$-acetylcysteine and vitamin E (600 $\mathrm{mg}$ /day). After 6 months of therapy, followed by 6 months of follow-up, no significant benefit between the 2 groups was seen in ALT levels or viral clearance at the end of treatment or during the follow-up period. ${ }^{44}$ Another randomized, controlled study looked at 47 patients with hepatitis $\mathrm{C}$ treated with either combination therapy (INF- $\alpha$ and ribavirin) or combination therapy and vitamin E (800 IU/day) for 24 weeks. At the end of treatment, no significant benefit was found between groups in terms of improvement of ALT or reducing ribavirin-induced hemolysis. ${ }^{45}$

Studies done in patients with chronic hepatitis B have suggested some benefit to treatment with vita-min E. For example, a RCT of 32 patients was done in patients with chronic hepatitis B treated with vitamin E (300 IU twice daily) for 3 months. Most patients were INF- $a$ nonresponders. Compared with placebo, the vitamin E group showed significant improvements in biochemical response (normalized ALT), virologic response (DNA negative), and complete response (both ALT normal and DNA negative). These results persisted throughout the follow-up period of 9-12 months. ${ }^{46}$

\section{Zinc}

Since the 1950s, it has been recognized that patients with cirrhosis of varying etiologies are zinc deficient. ${ }^{47-50}$ The clinical significance of this has been investigated in a number of specific disease states of the liver, looking at both underlying mechanisms as well as possible therapeutic options with zinc supplementation.

\section{Zinc in ALD}

\section{Pathophysiology}

It is well accepted that humans with ALD are zinc deficient. ${ }^{51}$ Human studies have shown decreased zinc absorption from the intestine and increased zinc excretion in the urine, decreased serum zinc concentrations, and decreased zinc content within the liver. ${ }^{52-55}$ Given the myriad of roles zinc plays within hepatic homeostasis, multiple mechanisms have been studied looking at its effects on ALD.

Alcohol is metabolized in the liver via 3 major pathways: alcohol dehydrogenase (ADH) in the cytosol, aldehyde dehydrogenase (ALDH) in the mitochondria, and microsomal ethanoloxidizing system in the endoplasmic reticulum. All 3 of these pathways generate reactive oxygen species (ROS). A large body of work has shown the microsomal ethanol-oxidizing system, especially the cytochrome P450 2E1 (CYP 2E1), to be a critical pathway in the generation of ROS in alcohol-induced liver damage, and it is thought that chronic ethanol exposure produces a relative shift in metabolism away from ADH toward CYP2E1. ${ }^{56-60}$ One proposed mecha nism for this shift is the effect zinc depletion has on ADH activity. $\mathrm{ADH}$ is a metalloenzyme dependent on the catalytic activity of zinc, and ADH activity has been shown to be zinc-dependent. ${ }^{61}$ Recently, zinc supplementation in ethanol-fed rats was 
shown to suppress CYP 2E1 activity, as well as increase the activity of ADH within the liver. ${ }^{62}$

In addition, zinc may play an important role in the glutathione (GSH) depletion found in ALD. Ethanol-fed rats have been shown to have reduced levels of GSH, an important antioxidant within the liver. ${ }^{63}$ In vitro depletion of zinc within hepatocytes induces a dosedependent decrease in GSH levels, and zinc supplementation in ethanol-fed rats has been shown to prevent ethanol-induced decreases in GSH levels. ${ }^{62,64}$

As mentioned earlier, $\mathrm{NF} \kappa \mathrm{B}$ activation within the liver plays a crucial role in the production of TNF- $\alpha$, a proinflammatory cytokine shown to be critical in the pathogenesis of ALD. ${ }^{65}$ The increased intestinal permeability and endotoxemia associated with ALD has been shown to increase $\mathrm{NF} \kappa \mathrm{B}$ activity and TNF- $\alpha$ production. In rats chronically fed ethanol, zinc supplementation prevented increases in TNF- $\alpha$ production. ${ }^{62}$ In rats exposed to endotoxin (lipopolysaccharide, LPS), zinc also prevented LPS-induced TNF- $a$ production via inhibition of $\mathrm{NF} \kappa \mathrm{B}$ activity. ${ }^{66} \mathrm{~A}$ study done in rats with acute alcohol-induced liver disease showed that pretreatment with zinc significantly inhibited TNF- $a$ elevation, increases in serum aminotransferases (ALT and AST) and histo-logic changes, presumably by inhibiting the endotoxemia associated with alcohol-induced liver disease. ${ }^{67}$

\section{Therapeutic Trials}

Although the underlying mechanisms of zinc deficiency in ALD have been extensively studied, there is a paucity of RCTs of zinc supplementation in patients with ALD. One study looked at 30 patients with compensated cirrhosis due to alcohol, treated with zinc or placebo. The treatment group received $200 \mathrm{mg} / \mathrm{day}$ of zinc for a total of 6 weeks. There was a significant decrease in serum bilirubin levels in the zinc-treated group, although this group also demonstrated a significant increase in prothrombin time. Dark adaption did not change between groups; however, there was a significant improvement in taste acuity in the patients treated with zinc. ${ }^{68}$ Several early, smaller studies have shown improvement in specific manifestations of zinc deficiency, such as skin lesions and impaired dark adaptation in alcoholic cirrhosis (as reviewed in McClain et $\mathrm{al}^{51}$ ).

\section{Zinc in Viral Hepatitis}

\section{Pathophysiology}

Zinc deficiency and its role in the pathogenesis and treatment of viral hepatitis is not well understood. Several small studies have evaluated serum zinc levels in patients with chronic viral hepatitis. ${ }^{69-74}$ The results have been mixed. Three found no significant differences when compared with controls; however, others have demonstrated a signifi-cant decrease in serum zinc levels when compared with controls. ${ }^{69-74}$ In one of these studies, a significant difference was found only in those patients with cirrhosis. ${ }^{72}$ Another of these studies only looked at patients with chronic hepatitis $\mathrm{C}$ and demonstrated that, in addition to lower serum zinc levels at baseline, these reductions were exacerbated further following injection of INF-

$a .{ }^{73}$ Based on these results, there has been some interest in using zinc supplementation as an adjunct to traditional antiviral therapy in patients with chronic hepatitis $\mathrm{C}$. The same group that reported lower serum zinc levels after injection of INF- $a$ into patients with chronic 
hepatitis $\mathrm{C}$ then followed these patients over 1 year. They measured serum zinc levels during and after 6 months of therapy with INF- $a$ and found that serum zinc levels were significantly higher in the patients achieving a sustained viral response (SVR) compared with nonresponders. ${ }^{73}$

\section{Therapeutic Trials}

As a result of the above study, a larger, randomized, controlled study was performed looking at treatment of patients with chronic hepatitis C with INF- $a v s$ INF- $a$ plus zinc. A total of 75 genotype $1 \mathrm{~b}$ patients were studied. The patients were given 10 million units of standard INF$a$ a day for 4 weeks, followed by the same dose every other day for 20 weeks. Patients in the combination therapy group (INF- $a+$ zinc) were treated with $150 \mathrm{mg} /$ day of zinc. At the end of 24 weeks, the authors found a significant improvement in complete response rate (normal ALT, undetectable HCV RNA polymerase chain reaction [PCR]) and incomplete response rate (normal ALT, detectable HCV RNA PCR) in the combination group in patients with a low viral load. In patients with high viral loads, there was no signifi-cant difference in complete or incomplete response rates between groups. Of note, there was a higher number of patients with a high viral load in the INF only group. ${ }^{75} \mathrm{~A}$ second randomized, controlled study looked at treatment of patients with chronic hepatitis $\mathrm{C}$ with standard $\alpha$-interferon-2a and ribavirin, treated with or without zinc supplementation. A total of 40 patients were studied. All patients were given 3 million units of INF 3 times a week and a weight-based dose of ribavirin daily. The treatment group was also given zinc gluconate (equivalent to 50 $\mathrm{mg}$ /day of zinc) beginning in the second week for 24 weeks. All patients were then followed for an additional 6 months. The authors found no signifi-cant difference between the rates of ETR or SVR between the 2 groups. However, they did find a significant decrease in the incidence of certain side effects from INF/ribavirin therapy in the zinc treatment group, specifically gastrointestinal disturbances, body weight loss, and mild anemia. Subgroup analysis based on genotype or viral load was not studied. ${ }^{76}$

\section{Zinc in Hepatic Encephalopathy}

\section{Pathophysiology}

In addition to studying its effects on certain types of liver disease, zinc also has been evaluated as a potential therapeutic agent for certain complications of cirrhosis, mainly hepatic encephalopathy. Zinc deficiency has been implicated as a possible component in the pathogenesis of hepatic encephalopathy, mainly through its role in the regulation of the urea cycle and ammonia metabolism. Ammonia has long been thought to be a central mediator in the development of hepatic encephalopathy. ${ }^{77}$ Ammonia derived from the gut is metabolized to urea in the liver, which is then excreted in the urine. In patients with both acute and chronic liver disease, elevated arterial levels of ammonia are common. In cirrhotic rats, zinc supplementation increased the activity of a key enzyme in the urea cycle and subsequently increased urea production and decreased ammonia levels. ${ }^{78}$

\section{Therapeutic Trials}

The available clinical data involving zinc and hepatic encephalopathy are mixed. One randomized controlled study (by Reding et al) looked at treatment of patients with hepatic 
encephalopathy with oral zinc supplementation. A total of 22 cirrhotic patients (etiology not disclosed) with stage I encephalopathy were randomized to $600 \mathrm{mg} /$ day of oral zinc sulfate supplementation or placebo. All patients were on lactulose and a low protein diet before enrollment. After 7 days, the zinc group had significantly higher serum levels of zinc and blood urea nitrogen (BUN) than controls. The zinc group also scored significantly higher on cognitive testing (trailmaking tests) than the placebo group, indicating an improvement in hepatic encephalopathy. ${ }^{79}$

Another RCT study looked at oral zinc supplementation in patients with hepatic encephalopathy. A total of 15 cirrhotic patients with hepatic encephalopathy were randomized to $600 \mathrm{mg} /$ day of oral zinc acetate supplementation or placebo in a doubleblind, crossover design. All patients were on lactu-lose and a low protein diet before enrollment. After 10 days, serum zinc levels in the treatment group increased to the same extent as in the previous study (1.59-fold in this study, 1.68-fold in the Reding study), but did not reach normal serum levels as in the previous study. The authors found no significant improvement between the 2 groups in a standardized hepatic encephalopathy index. ${ }^{80}$

A third nonrandomized, prospective study looked at patients with hepatic encephalopathy treated with oral zinc supplementation. Eight patients with cirrhosis and documented encephalopathy were treated with oral zinc sulfate $(600 \mathrm{mg} /$ day $)$ for 3 months and matched for cirrhosis and encephalopathy with 8 control patients. Both groups of patients were treated with lactulose and a low-protein diet. After 3 months, serum zinc levels returned to normal in the patients treated with oral zinc supplementation. In addition, zinc supplementation decreased basal ammonia levels and increased urea production. Psychometric testing also improved significantly from pretreatment levels in the patients treated with zinc, indicating an improvement in hepatic encephalopathy. ${ }^{81}$

A larger, randomized, controlled study evaluated patients with hepatic encephalopathy treated with oral zinc therapy. Ninety cirrhotic patients with compensated disease received standard therapy (low protein diet and lactulose) for 1 month and were then randomized to receive standard therapy or standard therapy plus oral zinc acetate $(600 \mathrm{mg} /$ day $)$ for 6 months. Although there were improvements in psychometric test values in the zinc-treated group, these results did not achieve statistical significance. ${ }^{82}$

\section{Zinc in Wilson's Disease}

\section{Pathophysiology}

Wilson's disease is an autosomal recessive genetic disease involving abnormalities in cellular copper export. This results in progressive accumulation of copper in the liver, as well as the brain, red blood cells, and kidneys. Liver disease is the most common clinical manifestation of Wilson's disease, and there is a broad spectrum of conditions ranging from asymptomatic elevations in liver function tests to fulminant hepatic failure.

Zinc has been well studied in the treatment of Wilson's disease and has been used extensively since the early 1960s. Zinc inhibits the absorption of copper from the gastrointestinal tract by inducing enterocyte metallothionein. Metallothionein is a protein

Nutr Clin Pract. Author manuscript; available in PMC 2014 November 21. 
that binds metals and has a high affinity for copper. It will preferentially bind copper present in the enterocyte absorbed from the gastrointestinal tract and inhibit it from entering the portal circulation. The enterocyte and bound copper are then excreted in the feces during normal cell turnover. ${ }^{83,84}$ Copper is also excreted in saliva and gastric secretions, and zinc can partially inhibit reabsorption of these secretions (thus creating a negative balance for copper) and remove stored copper. ${ }^{85}$

\section{Therapeutic Trials}

Long-term studies following patients over 10 years have demonstrated the efficacy of zinc used primarily as maintenance therapy in successfully treated patients and as first-line therapy in asymptomatic patients. ${ }^{86}$ The use of combination therapy with a chelating compound, such as trientine or D-penicillamine, and zinc in patients with active or symptomatic disease has been advocated but not extensively studied in large randomized, controlled trials. The dose of zinc that is usually required to impair copper absorption is 50 $\mathrm{mg}$ of elemental zinc (equivalent to $220 \mathrm{mg}$ zinc sulfate). Doses frequently used to treat Wilson's disease are $50 \mathrm{mg}$ elemental zinc 3 times a day. Long term zinc supplementation in other liver diseases should be under $50 \mathrm{mg}$ of elemental zinc/day to avoid side effects, including copper deficiency and GI distress.

\section{Magnesium}

\section{Pathophysiology}

It has been shown that patients with cirrhosis have low total body magnesium levels despite often normal-appearing serum ionized magnesium levels. ${ }^{87}$ This is thought to be due to a combination of factors, including poor absorption in the small bowel; enhanced urinary excretion from increased levels of aldosterone, growth hormone, and glucagon; and malnutrition. ${ }^{88}$ Magnesium deficiency has been postulated to play a role in the muscle cramps and weakness observed in many types of liver disease. Recently, hypomagnesemia has been implicated in the pathogenesis of specific disease states, especially NAFLD and NASH. Both conditions are strongly associated with insulin resistance, as well as obesity, type 2 diabetes mellitus, hypertriglyceridemia, and hypertension. It is thought that low magnesium levels may play a role in the development of insulin resistance. ${ }^{89}$ Hypomagnesemia has been reported in diabetic patients, and nondiabeticpatients with low plasma levels of magnesium have been found to be significantly more likely to have insulin resistance, glucose intolerance, and hyperinsulinemia when compared with controls with higher levels of magnesium. ${ }^{90,91}$ Magnesium levels have been shown to regulate cellular responsiveness to insulin, with low levels of magnesium producing cellular insulin resistance. ${ }^{92}$ A study done in 6 nondiabetic patients in which subjects were fed a low magnesium diet for 4 weeks also demonstrated that diet-induced magnesium deficiencies increased insulin resistance. ${ }^{93}$ Furthermore, an association between low magnesium levels and decreased glucose disposal has also been demonstrated in diabetic patients. ${ }^{94}$

\section{Therapeutic Trials}

Substantial recent evidence relates the glucose intolerance observed in NASH to magnesium deficiency. ${ }^{95}$ Further, there is a significant relation between low magnesium concentrations 
and both hepatic inflammation and fibrosis in NASH. ${ }^{95}$ Although preliminary evidence suggests a role for magnesium in the pathogenesis of NAFLD and NASH, few randomized, controlled trials have looked at treating patients with chronic liver disease with magnesium supplementation.

One study evaluated 59 patients with ALD treated for 6 weeks with both IV and oral magnesium supplementation ( $12.5 \mathrm{mmol} / \mathrm{day})$ vs placebo. After 6 weeks of therapy, the authors found no significant increase in muscle content of magnesium and no benefit in terms of muscle strength or mass in the treatment group. ${ }^{96}$ This study points out the potential difficulty repleting tissue magnesium stores. There have been no human studies with magnesium therapy on insulin resistance in patients with liver disease.

\section{S-Adenosylmethionine (SAMe)}

\section{Pathophysiology}

In mammals, the liver plays a central role in methionine metabolism, as nearly half of the daily intake of methionine is metabolized there. The first step in methionine metabolism is the formation of SAMe in a reaction catalyzed by methionine adenosyltransferase (MAT), and activity of this enzyme is depressed in many types of liver disease, especially ALD ${ }^{97,98}$ (Figure 1). SAMe is: (1) the principal biologic methyl donor via the transmethylation pathway; (2) the precursor of aminopropyl groups used in polyamine biosynthesis; and in liver (3), a precursor of GSH through its conversion to cysteine via the transsulfuration pathway. ${ }^{97,98}$ The normal human adult produces $6-8 \mathrm{~g}$ of SAMe per day, most of it in the liver, where it is also used in a variety of reactions. Under normal conditions, most of the SAMe generated per day is used in transmethylation reactions in which methyl groups are added to a vast number of molecules, including both high-and low-molecular-weight compounds, via specific methyltransferases. ${ }^{99-101}$ These compounds include DNA, RNA, biogenic amines, phospholipids, his-tones, and other proteins; their methylation may modulate cellular functions and integrity. In thisprocess, SAMe is converted to $S$ adenosylhomocysteine (SAH), which is a potent competitive inhibitor of most methyltransferases studied. Both an increase in SAH level as well as a decrease in the SAMe:SAH ratio are known to inhibit transmethylation reactions. ${ }^{100-102}$

SAMe deficiency has been observed in many forms of liver disease and was first identified in ALD in the early 1980s, when it was observed that alcoholic subjects had delayed clearance of an oral bolus of methionine (presumably due to a blocked conversion of methionine to SAMe). ${ }^{103}$ Subse quently, Mato and his group ${ }^{97,104}$ confirmed this postulate and demonstrated that the functional MAT was indeed subnormal in liver biopsies from alcoholic subjects. In addition to ALD, subnormal hepatic SAMe is also noted in various experimental models of liver injury, such as steatosis, cholestasis, or toxins such as ethanol, $\mathrm{CCl}_{4}$, acetaminophen, or galactosamine. Exogenous SAMe administration corrects the deficiency and attenuates liver injury. ${ }^{105-107}$

Although SAMe deficiency has been reported in several liver diseases, the mechanism(s) by which SAMe levels modulate hepatotoxicity are not fully understood. Because SAMe is a precursor for GSH synthesis, SAMe deficiency results in GSH deficiency, which is observed 
in many forms of liver disease. ${ }^{108}$ In animal studies, exogenous SAMe corrected hepatic deficiencies of both SAMe and GSH. ${ }^{109}$ Because GSH is required for optimal expression of MAT activity in the liver, hepatic deficiency of MAT may in part be due to GSH deficiency. Also, hepatic MAT is sensitive to oxidative stress, and oxidation of cys 121, the active site of the enzyme located in its flexible loop, results in loss of its activity. Thus, subnormal hepatic MAT activity in ALD patients could occur due to oxidation of the active site by increased oxidative stress. ${ }^{110}$ In addition, in alcohol-induced models of hepatotoxicity, SAMe has been shown to maintain mitochondrial GSH levels. Depletion of mitochondrial GSH is thought to be one etiologic factor in the development of ALD, and SAMe, but not other GSH pro-drugs, prevented mitochondrial GSH depletion (possibly by protecting mitochondrial GSH transport systems). ${ }^{111}$ SAMe also positively regulates cytokine metabolism. ${ }^{99}$ Thus, low SAMe levels augment endotoxin-stimulated TNF production, whereas SAMe supplementation decreases TNF. ${ }^{99}$ On the other hand, SAMe increases the production of the "good" anti-inflammatory cytokine, interleukin-10 (IL-10). ${ }^{99}$ Thus, SAMe deficiency appears to augment inflammation and SAMe supplementation decreases inflammation. ${ }^{99}$

\section{Therapeutic Trials}

SAMe has been used in a variety of animal studies and European clinical trials and has been reported to improve biochemical parameters of liver function. For example, Loguercio et al $^{112}$ reported that parenteral treatment of alcoholic patients with SAMe ( $2 \mathrm{~g} /$ day for 15 days IV) improved erythrocyte GSH concentrations, suggesting an attenuation of oxidative stress. Similar improvements have been reported in patients with alcoholic and primary biliary cirrhosis. ${ }^{113}$ Patients with intrahepatic cholestasis were also administered SAMe, and improvements in their serum transaminases and bilirubin have been reported by several workers. ${ }^{13-115}$ A pivotal study from Mato's group reported that SAMe supplementation improved mortality and decreased need for liver transplantation in patients with less severe alcoholic cirrhosis. ${ }^{116}$ This was a multicenter trial from Spain enrolling 123 patients. SAMe was given in a dose of $1200 \mathrm{mg} /$ day in this 2 year, randomized, placebo-controlled trial. This is the largest SAMe study in cirrhosis, and it used what we consider appropriate dosing. Several previous studies probably used inadequate dosing; we currently prescribe 1600 $\mathrm{mg} / \mathrm{day}$ (400 mg 4 times daily) in alcoholic cirrhosis and in NASH.

\section{Betaine}

\section{Pathophysiology}

Betaine (trimethylglycine) was initially discovered in the juice of sugar beets. Betaine functions as an organic osmolyte to protect cells from stress, and it also functions as a major methyl donor in the methionine cycle (Figure 1). ${ }^{117}$ Thus, it is appropriate to discuss SAMe and betaine together. In the transmethylation pathway, SAMe is converted to SAH. While SAMe levels tend to be low in most forms of liver disease, SAH levels are elevated, as are homocysteine levels. ${ }^{118} \mathrm{SAH}$ can sensitize hepatocytes to TNF-induced hepatotoxicity, and homo-cysteine is a major inducer of fatty liver. ${ }^{118}$ Thus, it is important to be able to remove excess levels of both $\mathrm{SAH}$ and homocysteine from the liver. ${ }^{89}$ 
Betaine facilitates the conversion of homocysteine back to methionine and helps remove both SAH and homocysteine (Figure 1). Animals injected with betaine demonstrate a dosedependent increase in red blood cell SAMe, again documenting the potential overlapping roles of SAMe and betaine in therapy of different forms of liver disease. Betaine is known to be protective against a variety of forms of experimental hepatotoxicity such as those induced by endotoxin, carbon tetrachloride, chloroform, alcohol, and others. ${ }^{19-122}$ As noted previously, low levels of SAMe are observed in most forms of liver disease, and SAMe serves as a hepatoprotective agent. Betaine functions by removing SAH and homocysteine from the liver, as well as regenerating SAMe.

Abnormalities in SAH and homocysteine levels are now being recognized in both experimental forms of liver injury and human injury. Our group, ${ }^{118}$ others, ${ }^{122}$ and Barak et $\mathrm{al}^{123}$ have documented elevatedSAH levels in experimental models of liver disease, and studies by several groups document elevated homocysteine levels in animal models of liver injury. As noted previously, the SAMe:SAH ratio and SAH levels critically regulate transmethylation reactions (with increased SAH inhibiting transmethylation reactions). Studies from Ji and Kaplowitz ${ }^{122}$ reported that hyperhomocysteinemia induced endoplasmic reticulum stress with subsequent liver injury in alcohol-fed mice, and removal of homocysteine by betaine supplementation attenuated fatty liver and liver injury. Studies from Barak and coworkers ${ }^{123}$ clearly indicated that betaine removes not only homocysteine but also SAH (see Figure 1). Our studies document that elevated SAH levels sensitize to TNF-induced hepatotoxicity, and we postulate that this is a clinically relevant sensitizer to TNF hepatotoxicity in ALD. ${ }^{118}$ Importantly, elevated SAH level and altered SAMe:SAH ratio likely cause disruption of hepatic transmethylation reactions. This is consistent with previous research by Lieber et al ${ }^{124}$ showing that alcohol consumption decreased hepatic phosphatidylethanolamine $N$-methyltransferase (PEMT) activity in a baboon model of alcohol-induced hepatic fibrosis. Recent studies by Lu's group ${ }^{125}$ documented decreased mRNA for multiple methyltransferases in liver biopsies from patients with alcoholic hepatitis. Methylation involves conversion of cytosine to 5-methylcytosine in reactions mediated by specific DNA methyltransferases. The extent of methylation of cytosine to 5methylcytosine often is correlated with gene activity. Hypermethylation is associated with nonexpression of the gene, whereas hypomethylation is a necessary but not sufficient condition for gene expression. ${ }^{126-128}$ For example, caspase- 8 gene expression is sensitive to intracellular methylation status. ${ }^{129,130}$ We have observed that increased intracellular SAH levels modulate caspase- 8 expression and activity after TNF exposure in hepatocytes (increased intracellular SAH increasing caspase-8 expression). ${ }^{118}$ Thus, increased SAH levels and hypomethylation could critically influence pathways ranging from fat accumulation in the liver (eg, PEMT, which is critically involved in very low density lipoprotein [VLDL] production) to caspase-8 expression/activity, which could play a role in enhanced apoptosis of in many forms of liver injury such as ALD. ${ }^{118,125,131}$ Thus, betaine therapy in theory could both decrease fatty infiltration in the liver, as well as decrease hepatocyte death. 


\section{Therapeutic Trials}

Betaine has been used in a pilot trial of 10 NASH patients from the Mayo Clinic. ${ }^{132}$ Betaine was given at a dose of $10 \mathrm{~g}$ orally twice per day for 1 year. Patients had a significant improvement in liver enzymes and liver histology including fat, inflammation, and fibrosis. ${ }^{132}$ Larger studies are ongoing with this agent in NASH at similar doses, and preliminary data seem very promising.

\section{Silymarin (Milk Thistle)}

\section{Pathophysiology}

Silymarin is the active ingredient extracted from Silybium marianum (milk thistle), a member of the daisy family, whose leaves have prominent white "milky" veins. ${ }^{133}$ This agent protects animals against multiple types of experimental liver injury, such as carbon tetrachloride, acetaminophen, iron overload, bile duct obstruction, and, very importantly, amanita mushroom poisoning. ${ }^{133-135}$ In several animal species, the agent was effective in both pretreatment phases as well as after ingestion. ${ }^{133-135}$ Claims for use as an antidote for acute amanita poisoning in humans have been made, but its efficacy is less clear. Further, the supplement is poorly absorbed, and content of preparations is highly variable. The proposed mechanisms of action of silymarin are multiple and listed below:

\section{Antioxidant Action}

Silymarin acts as an antioxidant by scavenging ROS such as hydroxyl radicals and hypohalide derivatives (eg, hypochlorous acid). ${ }^{136-138}$ Consistent with such effects, silymarin also increases GSH content in the liver, stomach, and intestine. ${ }^{139}$ In erythrocytes and lymphocytes of patients with ALD, silymarin augmented the activity of superoxide dismutase (SOD), an enzyme that dissipates the super-oxide anion. ${ }^{140}$ Importantly, silymarin inhibited the oxidative burst (superoxide anion production) generated by activated human neutrophils. ${ }^{141}$

\section{Modulation of Cytokine Metabolism}

Silymarin has been reported to suppress TNF- $\alpha$-induced NF $k$ B activation, to inhibit TNF- $\alpha$ induced cytotoxicity, and caspase activation. ${ }^{142}$ These effects are highly relevant for the liver protection against TNF- $\alpha$-induced hepatotoxicity that can occur in ALD, toxin-induced liver injury, and NASH. Also, silymarin protected the liver against T-cell-induced injury (in the concanavalin A model) and concomitantly increased the expression of IL-10, an antiinflammatory cytokine, and decreased the expression of TNF- $a$, a proinflammatory cytokine in the liver. ${ }^{143}$

\section{Interference With Lipid Metabolism}

Silymarin inhibited lipid peroxidation in rat liver peroxisomes and in freshly isolated rat hepatocytes and exerted a transient inhibitory effect on fatty acid synthesis in the rat liver. ${ }^{144,145}$ 


\section{Protective Action Against Alcohol}

Silymarin protected primary human hepatocytes in culture against deleterious effects of alcohol andmarkedly attenuated the progression of alcohol-induced hepatic fibrosis in the baboon. ${ }^{146,147}$

\section{Liver Fibrosis}

Stellate cell transformation into fibroblasts with the simultaneous increase in extracellular matrix protein secretion has been shown to be inhibited by silymarin. ${ }^{148}$

\section{Enhanced Liver Regeneration}

An intriguing effect of silymarin is its ability to enhance the liver regenerative capacity after partial hepatectomy in the rat. ${ }^{149}$ The above findings demonstrate that silymarin is a potent protective agent of the liver against a wide spectrum of injurious agents.

\section{Therapeutic Trials}

In the United States, silymarin is probably the most widely used form of CAM in the treatment of liver disease. Claims have been made for its hepatoprotective effects in various forms of toxic hepatitis, fatty liver, cirrhosis, ischemic injury, and viral-induced liver disease ${ }^{133,134}$ due to its antioxidant activities, anti-inflammatory and antifibrotic effects. Controlled trials of silymarin have been performed in Europe, with variable results. A positive beneficial effect, especially in patients with alcoholic cirrhosis and in those with milder disease, was found with a treatment program ( $140 \mathrm{mg} 3$ times/day) having a mean duration of 41 months. ${ }^{136}$ Conversely, no beneficial effects were found using $150 \mathrm{mg}$ silymarin 3 times per day in a study of 200 patients with alcoholic cirrhosis, some of whom also had hepatitis C. ${ }^{150}$ Both of these trials had major shortcomings, including high dropout rates and compliance issues. Silymarin has been shown to improve insulin resistance in alcoholic cirrhotics. ${ }^{151}$ Silymarin is likely to remain one of the more popular forms of CAM therapy for liver disease because it has a good safety profile, it has been extensively investigated in multiple forms of experimental liver injury in animals, and some positive results have been reported in humans. The NIH is currently funding large clinical trials to further define the mechanism(s) of action and efficacy in diseases such as hepatitis $\mathrm{C}$ and NASH.

\section{Glycyrrhizin (Licorice Root)}

\section{Pathophysiology}

The active component of Glycyrrhiza glabra (licorice root) is glycyrrhizin, which is a combination of glycyrrhetinic acid and glucuronic acid. The use of licorice has been traced back to the early 16th century, used initially in the Mediterranean and Middle East and later in Europe. This root was used for its antiallergic, detoxifying, and antiviral effects. It has been used for various conditions, including malaria, peptic ulcers, pharyngitis, bronchitis, as well as hepatitis. ${ }^{152}$

Proposed mechanisms of action for the hepatoprotective effects of glycyrrhizin include its antilipid perioxidation, antioxidant, immunosuppressive, and anti-inflammatory 
characteristics. ${ }^{133,153-155}$ In vitro studies with human hepatoma cell lines showed that glycyrrhizin prevented the hepatitis A virus from cellular entry by inducing alterations on human cellular membranes. ${ }^{156}$ Glycyrrhizin also inhibited the activation of phospholipase A2, decreasing levels of ALT release by hepatocytes. ${ }^{157}$ Glycyrrhizin has been reported to enhance INF- $\gamma$ production and stimulation of natural killer cell activity, thus preventing inflammation of hepatocytes. Last, Okamoto ${ }^{158}$ showed that glycyrrhizin inhibited the Fas ligand, a major inducer of apoptosis, which was thought to provide another pathway where this herb prevents inflammation in hepatocytes with hepatitis $\mathrm{C}$.

Animal models have shown that glycyrrhizin decreased P450 metabolic reactions and enhanced hepatic glucuronidation. ${ }^{152,159}$ Glycyrrhizin-treated mice demonstrated enhanced production of endogenous interferon, ${ }^{160}$ and another mouse study showed that glycyrrhizin inhibited production of TNF and hepatic fibrogenesis. ${ }^{153}$ An animal model study by Abe et $\mathrm{al}^{161}$ showed that the rat liver dendritic cells increased production of IL-10 when exposed to glycyrrhizin, and this was associated with attenuated concanavalin-A-induced hepatitis and hepatic inflammation, as well as carbon tetrachloride-induced liver injury. This was confirmed in vitro using rat liver dendritic cells in culture.

\section{Therapeutic Trials}

Clinical trials using glycyrrhizin (IV) have mostly involved the treatment of hepatitis C, specifically, patients who are refractory to, or intolerant of, interferon treatment. Trials were generally difficult to interpret due to small sample size, weak methodology, lack of defined outcomes and nonhomogeneity of liver diagnoses. A double-blinded randomized trial performed by Suzuki et al ${ }^{162}$ looked at IV injections of $80 \mathrm{mg}$ of Stronger Neo-Minophagen $\mathrm{C}$ (SNMC, the Japanese standard preparation of glycyrrhizin combined with glycine and cysteine) in patients who had histologically proven, chronic active hepatitis. After 1 month's treatment in 133 patients, transaminases fell by about $40 \%$ in the treatment group vs the $2 \%$ drop in the placebo group, and no significant side effects were noted. However, this study has major limitations due to such a short duration. A retrospective study performed by Arase et al ${ }^{163}$ showed that ALT levels dropped and the overall rate of hepatocellular carcinoma was lower with $200 \mathrm{mg}$ of glycyrrhizin given 5 days per week in hepatitis $\mathrm{C}$ patients compared with untreated patients. This study had a 10- to 15-year follow-up, but there was limited information on thedemographics of the 193 participating patients. The authors believed that glycyrrhizin therapy may be beneficial since normalization of serum transaminases appeared to be a key prognostic factor for the development of histologic changes and progression to hepatocellular carcinoma. ${ }^{163,164}$ Further, low serum ALT levels reduced the risk of post-therapeutic recurrence after resection of a preceding tumor. ${ }^{165}$ Hence, glycyrrhizin may provide clinical benefits in prevention of hepatocellular carcinoma in chronic hepatitis $\mathrm{C}$ refractory to interferon therapy or in patients who are not candidates for interferon therapy. In summary, most clinical trials (often in hepatitis $\mathrm{C}$ interferon nonresponders) have found a consistent decrease in transaminases, and at least 1 study reported that glycyrrhizin demonstrates dose-dependent efficacy. ${ }^{166}$ The beneficial effects of glycyrrhizin seem to be lost once treatment has been stopped, which is a major disadvantage if IV dosing is used. 
As mentioned earlier, glycyrrhizin had been found in in vitro studies to produce endogenous interferon. Thus, this therapy could, in theory, enhance standard interferon treatment for hepatitis C. Fujiyama et a ${ }^{167}$ looked at 101 patients in an open comparative trial, dividing patients into 3 different treatment arms: INF- $a 2 b$ alone (10 MU/day subcutaneously for 2 weeks; then 3 times per week for 22 weeks), INF- $a$ 2b plus SNMC (for 24 weeks; then SNMC alone for 24 weeks), and INF- $a 2 \mathrm{~b}$ alone (10 MU/day for 4 weeks; then 3 times per week for 20 weeks). No significant differences were found between the 3 arms at any time in terms of serum liver markers. Further, INF- $a 2 b$ alone was found to provide the most effective viral response as opposed to the combination therapy. A smaller study compared INF- $a$ (6 MU per day for 8 weeks) $v s$ INF- $a$ plus SNMC for 8 weeks. ${ }^{168}$ Again, no significant changes in serum biomarkers and virological response were seen at 8 weeks and at 6 months of follow-up. Thus, very limited studies have not shown enhanced antiviral effects with glycyrrhizin.

Glycyrrhizin has some safety issues that have limited our enthusiasm for this agent.

Glycyrrhizin causes a "pseudoaldosterone effect," especially in those who have predisposing sodium-retaining conditions like ascites, heart failure, nephrotic disease, and hypertension. ${ }^{169,170}$ This effect is related to glycyrrhizin's inhibition of the enzyme 11- $\beta$ hydroxysteriod dehydrogenase, which triggers an increase in salt retention. Potassium depletion may also complicate comorbid conditions, and potential drug interactions may occur, specifically with drugs that are metabolized by the CYP450 3A4. Licorice root maycontain coumarins or coumarin derivatives and may inhibit platelet aggregation. Also, licorice root may decrease the effectiveness of angiotension-converting enzyme inhibitors and angiotension II receptor antagonists. ${ }^{171}$

\section{Selected Other CAM Agents}

There are several other CAM agents that may have some efficacy in liver disease. We have selected some of the more widely recognized agents, listed in Table 1 with appropriate references.

\section{Hepatotoxicity and Safety Issues}

Nutrition supplements/CAM agents can serve as effective therapeutic agents for liver disease but may also induce hepatotoxicity. ${ }^{9}$ Indeed, dietary supplements are under less governmental control than over-the-counter nonprescription drugs. Thus, both healthcare workers and the general public must understand that the labeling of CAM products is not necessarily correct, that the advertised dose might not be correct, and these agents may not be pure. Safety issues concerning CAM agents relate to both the content of the product and the potential harm that can be induced. Multiple studies have documented great variability in the composition of certain herbal products and supplements. This variability is likely unavoidable in many Chinese herbal compounds. Thus, traditional prospective randomized clinical trials are often difficult to perform because of the great variability in these agents.

Hepatotoxicity is a major safety issue in many CAM agents, similar to prescription drugs. Thewell-publicized hepatotoxicity of some agents such as kava kava have increased both 
public and health-care provider awareness of this problem. ${ }^{193}$ Table 2 lists some of the CAM agents that have documented hepatotoxicity.

CAM agents can also be contaminated with toxins or other drugs. ${ }^{207,208}$ For example, some Chinese patent medicines contain small amounts of prescription drugs such as antibiotics. These drugs may also be contaminated with heavy metals, such as lead or mercury. CAM agents can also interact with traditional medicines. One such example is the interaction of St. Johns Wort with indicavir and cyclosporin. ${ }^{209,210}$ This interaction was highlighted when patients who had undergone heart transplants developed rejection episodes after starting St. Johns Wort, presumably because of the induction of cyto-chrome P4503A4 by St. Johns Wort.

There are also natural nutrient:nutrient interactions, such as zinc interacting with copper. Thus, high-dose zinc supplementation will impair copper absorption and can induce copper deficiency. Indeed, as described previously, zinc is used therapeutically in Wilson's disease for this exact "side effect" of producing copper deficiency. ${ }^{211}$

Last, nutrition supplement studies receive much lay press publicity, and this may inappropriately increase concerns about nutrition supplements/ CAM agents and may inappropriately decrease their use by the public. One such example is a recent meta analysis of "high-dose" vitamin E. ${ }^{212}$ This study used highly selected patient populations that did not include trials on liver disease. Vitamin E, as discussed previously, is highly effective at preventing hepatotoxicity and fibrosis induced by a variety of toxins and infectious agents in experimental animals. Many initial clinical trials of vitamin E in liver disease have demonstrated favorable results. However, many patients and physicians have stopped using high-dose vitamin E supplementation because of just this one study.

\section{Conclusions}

Malnutrition and isolated nutrient deficiencies are quite common in liver disease, especially in more advanced liver disease. There are emerging data that certain nutrition supplements/CAM agents may not only correct nutrition deficiencies but may also have therapeutic effects. This is especially important in the areas of fibrosis (where no effective FDA agents are approved) and in the rapidly expanding area of NAFLD. We frequently use zinc supplementation as an adjunct therapy for hepatic encephalopathy and regularly give zinc supplements to patients with cirrhosis because they are almost always zinc deficient. Many of our patients already are taking supplements such as milk thistle and SAMe, and we attempt to provide patients with information on dosing, potential side effects, and issues concerning product safety. Individual and multicenter trials supported by the NIH evaluating agents such as vitamin E, milk thistle, and SAMe are ongoing, and we eagerly await preliminary results.

\section{Acknowledgments}

Supported by NIH grants K24AA000297 (Hill), RO1AA014185 (Hill), RO1AA010496 (McClain), R37AA010762 (McClain), RO1AA015970 (McClain), RO1DK071765 (McClain), and the Veterans Administration (McClain).

Nutr Clin Pract. Author manuscript; available in PMC 2014 November 21. 


\section{References}

1. McClain, CJ.; Hill, DB.; Kugelmas, M.; Marsano, L. Nutrition and liver disease. In: Bowman, B.; Russell, RM., editors. Present Knowledge in Nutrition. ILSI Press; Washington, DC: 2001. p. 483-496.

2. Mendenhall C, Roselle GA, Gartside P, Moritz T. Relationship of protein calorie malnutrition to alcoholic liver disease: a reexamination of data from two Veterans Administration cooperative studies. Alcohol Clin Exp Res. 1995; 19:635-641. [PubMed: 7573786]

3. Mendenhall CL, Tosch T, Weesner RE, et al. VA cooperative study on alcoholic hepatitis II: prognostic significance of protein-calorie malnutrition. Am J Clin Nutr. 1986; 43:213-218. [PubMed: 3080866]

4. Mendenhall CL, Anderson S, Weesner RE, Goldberg SJ, Krolik KA. Protein-calorie malnutrition associated with alcoholic hepatitis. Am J Med. 1984; 76:211-222. [PubMed: 6421159]

5. Mendenhall CL, Moritz TE, Roselle GA, et al. A study of oral nutritional support with oxandrolone in malnourished patients with alcoholic hepatitis: results of a Department of Veterans Affairs Cooperative Study. Hepatology. 1993; 17:564-576. [PubMed: 8477961]

6. Mendenhall CL, Moritz TE, Roselle GA, et al. Protein energy malnutrition in severe alcoholic hepatitis: diagnosis and response to treatment: the VA Cooperative Study Group \#275. JPEN J Parenter Enteral Nutr. 1995; 19:258-265. [PubMed: 8523623]

7. Sarin SK, Dhingra N, Bansal A, Malhotra S, Guptan RC. Dietary and nutritional abnormalities in alcoholic liver disease: a comparison with chronic alcoholics without liver disease. Am J Gastroenterol. 1997; 92:777-783. [PubMed: 9149184]

8. Caregaro L, Alberino F, Amodio P, et al. Malnutrition in alcoholic and virus-related cirrhosis. Am J Clin Nutr. 1996; 63:602-609. [PubMed: 8599326]

9. McClain, CJ.; Dryden, G.; Krueger, K. Complementary and Alternative Medicine in Gastroenterology: Textbook of Gastroenterology. 4th ed. Vol. Vol 1. Lippincott Williams \& Wilkins; Philadelphia, PA: 2003. p. 1135-1146.

10. Eisenberg DM, Kessler DM, Kessler RC, Norlock FE, Calkins DR, Delbanco DL. Unconventional medicine in the United States: prevalence, costs, and patterns of use. N Engl J Med. 1993; 328:246-252. [PubMed: 8418405]

11. Eisenberg DM, Davis RB, Ettner SL, et al. Trends in alternative medicine use in the United States, 1990-1997: results of a follow-up national survey. JAMA. 1998; 280:1569-1575. [PubMed: 9820257]

12. Krueger KJ, McClain CJ, McClave SA, Dryden GW. Nutritional supplements and alternative medicine. Curr Opin Gastroenterol. 2004; 20:130-138. [PubMed: 15703634]

13. Tilg H, Diehl AM. Cytokines in alcoholic and nonalcoholic steatohepatitis. N Engl J Med. 2000; 343:1467-1476. [PubMed: 11078773]

14. Hill DB, Barve S, Joshi-Barve S, McClain C. Increased monocyte nuclear factor-NF- $\kappa$ B activation and tumor necrosis factor production in alcoholic hepatitis. J Lab Clin Med. 2000; 135:387-395. [PubMed: 10811053]

15. Arteel G, Marsano L, Mendez C, Bentley F, McClain CJ. Advances in alcoholic liver disease. Best Pract Res Clin Gastroenterol. 2003; 17:625-647. [PubMed: 12828959]

16. Schrek R, Rieber P, Baeuerle PA. Reactive oxygen intermediates as apparently widely used messengers in the activation of the NF-kB and AP-1 in lymphocytes. EMBO J. 1991; 10:22472258. [PubMed: 2065663]

17. Schultze-Osthoff K, Los M, Baeuerle P. Redox signaling by transcription factors NF-kB and AP-1 in lymphocytes. Biochem Pharmacol. 1995; 50:735-741. [PubMed: 7575632]

18. Mandrekar P, Catalano D, Szabo G. Alcohol-induced regulation on nuclear regulatory factor NF$\kappa \mathrm{B}$ in human monocytes. Alcohol Clin Exp Res. 1997; 21:988-994. [PubMed: 9309306]

19. Hill DB, Devalaraja R, Joshi-Barve S, Barve S, McClain CJ. Antioxidants attenuate nuclear factorkappa B activation and tumor necrosis factor-alpha production in alcoholic hepatits patient monocytes and rat kupfer cells, in vitro. Clin Biochem. 1999; 32:563-570. [PubMed: 10614719]

20. McClain CJ, Mokshagundam SP, Barve SS, et al. Mechanisms of non-alcoholic steatohepatitis. Alcohol. 2004; 34:67-79. [PubMed: 15670668] 
21. Kugelmas M, Hill DB, Vivian B, Marsano L, McClain CJ. Cytokines and NASH: a pilot study of the effects of lifestyle modification and vitamin E. Hepatology. 2003; 38:413-419. [PubMed: 12883485]

22. Crespo J, Cayon A, Fernandez-Gill P, et al. Gene expression of tumor necrosis factor $a$ and TNFreceptors, p55 and p75, in nonalcoholic steatohepatitis patients. Hepatology. 2001; 34:1158-1163. [PubMed: 11732005]

23. Wigg AJ, Roberts-Thomson IC, Dymock RB, McCarthy PJ, Grose RH, Cummins AG. The role of small intestinal bacterial over-growth, intestinal permeability, endotoxaemia, and tumour necrosis factor $a$ in the pathogenesis of non-alcoholic steatohepatitis. Gut. 2001; 48:206-211. [PubMed: 11156641]

24. Pena AD, Leclercq I, Field J, George J, Jones B, Farrell G. NF- $\kappa$ B activation, rather than TNF, mediates hepatic inflammation in a murine dietary model of steatohepatitis. Gastroenterology. 2005; 129:1663-1674. [PubMed: 16285964]

25. Lee KS, Buck M, Houghlum K, Chojkier M. Activation of hepatic stellate cells by TGF alpha and collagen type 1 is mediated by oxidative stress through c-myb expression. J Clin Invest. 1995; 96:2461-2468. [PubMed: 7593635]

26. Parola M, Leonarduzzi G, Biasi F, et al. Vitamin E dietary supplementation protects against carbon tetrachloride-induced chronic liver damage and cirrhosis. Hepatology. 1992; 16:1014-1021. [PubMed: 1398481]

27. Liu S, Esposti SD, Yao T, Diehl AM, Zern M. Vitamin E therapy of acute CCl4-induced hepatic injury in mice is associated with inhibition of nuclear factor kappa B binding. Hepatology. 1995; 22:1474-1481. [PubMed: 7590666]

28. Parola M, Muraca R, Dianzani I, et al. Vitamin E dietary supplementation inhibits transforming growth factor $\beta 1$ gene expression in the rat liver. FEBS Lett. 1992; 308:267-270. [PubMed: 1505665]

29. Lavine JE. Vitamin E treatment of nonalcoholic steatohepatitis in children: a pilot study. J Pediatr. 2000; 136:734-738. [PubMed: 10839868]

30. Vajro P, Mandato C, Franzese A, et al. Vitamin E treatment in pediatric obesity-related liver disease: a randomized study. J Pediatr Gastroenterol Nutr. 2004; 38:48-55. [PubMed: 14676594]

31. Hasegawa T, Yoneda M, Nakamura K, Makino I, Terano A. Plasma transforming growth factor- $\beta 1$ level and efficacy of $a$-tocopherol in patients with non-alcoholic steatohepatitis: a pilot study. Aliment Pharmacol Ther. 2001; 15:1667-1672. [PubMed: 11564008]

32. Sanyal AJ, Mofrad PS, Contos MJ, et al. A pilot study of vitamin E versus vitamin E and pioglitazone for the treatment of nonalcoholic steatohepatitis. Clin Gastroenterol Hepatol. 2004; 2:1107-1115. [PubMed: 15625656]

33. Nanji AA, Yang EK, Fogt F, Sadrzadeh SM, Dannenberg AJ. Medium chain triglycerides and vitamin $\mathrm{E}$ reduce the severity of established experimental alcoholic liver disease. J Pharmacol Exp Ther. 1996; 277:1694-1700. [PubMed: 8667240]

34. Butcher GP, Rhodes JM, Walker R, Krasner N, Jackson MJ. The effect of antioxidant supplementation on the serum marker of free radical activity and abnormal serum biochemistry in alcoholic patients admitted for detoxification. J Hepatol. 1993; 19:105-109. [PubMed: 8301030]

35. de la Maza MP, Petermann M, Bunout D, Hirsch S. Effects of long-term vitamin E supplementation in alcoholic cirrhotics. J Am Coll Nutr. 1995; 14:192-196. [PubMed: 7790695]

36. Mezey E, Potter JJ, Rennie-Tankersley L, Caballeria J, Pares A. A randomized placebo controlled trial of vitamin E for alcoholic hepatitis. J Hepatol. 2004; 40:40-46. [PubMed: 14672612]

37. Farinati F, Cardin R, De Maria N, et al. Iron storage, lipid peroxidation and glutathione turnover in chronic anti HCV-positive hepatitis. J Hepatol. 1995; 22:449-456. [PubMed: 7545199]

38. De Maria N, Colantoni A, Fagiuoli S, et al. Association between reactive oxygen species and disease activity in chronic hepatitis C. Free Radic Biol Med. 1996; 21:291-295. [PubMed: 8855439]

39. Shimoda R, Nagashima M, Sakamoto M, et al. Increased formation of oxidative DNA-damage 8hydroxydeoxyguanosine in human livers with chronic hepatitis. Cancer Res. 1994; 54:3171-3172. [PubMed: 8205535] 
40. Houglum K, Venkataramani A, Lyche K, Chojkier M. A pilot study of the effects of d-alphatocopherol on hepatic stellate cell activation in chronic hepatitis C. Gastroenterology. 1997; 113:1069-1073. [PubMed: 9322499]

41. Mahmood S, Yamada G, Niiyama G, et al. Effect of vitamin E on serum aminotransferase and thioredoxin levels in patients with viral hepatitis C. Free Radic Res. 2003; 37:781-785. [PubMed: 12911275]

42. von Herbay A, Stahl W, Niederau C, Sies H. Vitamin E improves the aminotransferase status of patients suffering from viral hepatitis C: a randomized, double-blind, placebo-controlled study. Free Radic Res. 1997; 27:599-605. [PubMed: 9455695]

43. Look MP, Gerard A, Rao GS, et al. Interferon/antioxidant combination therapy for chronic hepatitis C: a controlled pilot trial. Antiviral Res. 1999; 43:113-122. [PubMed: 10517313]

44. Ideo G, Bellobuono A, Tempini S, et al. Antioxidant drugs combined with alpha-interferon in chronic hepatitis $\mathrm{C}$ not responsive to alpha-interferon alone: a randomized, multicentre study. Eur J Gastroenterol Hepatol. 1999; 11:1203-1207. [PubMed: 10563527]

45. Saeian K, Bajaj JS, Franco J, et al. for the Midwest Hepatitis Study Group. High dose vitamin E supplementation does not diminish ribavirin-associated haemolysis in hepatitis $\mathrm{C}$ treatment with combination standard alpha-interferon and ribavirin. Aliment Pharmacol Ther. 2004; 20:11891193. [PubMed: 15569122]

46. Andreone P, Fiorino S, Cursaro C, et al. Vitamin E as treatment for chronic hepatitis B: results of a randomized controlled pilot trial. Antiviral Res. 2001; 49:75-81. [PubMed: 11248360]

47. Vallee BL, Wacker WEC, Bartholomay AF, Robin ED. Zinc metabolism in hepatic dysfunction, I: serum zinc concentrations in Laennec's cirrhosis and their validation by sequential analysis. $\mathrm{N}$ Engl J Med. 1956; 255:403-408. [PubMed: 13358854]

48. Vallee BL, Wacker WEC, Bartholomay AF, Hoch FLH. Zinc metabolism in hepatic dysfunction, II: correlation of metabolic patterns with biochemical findings. N Engl J Med. 1957; 257:10551065. [PubMed: 13483888]

49. Halsted JA, Hackley B, Rudzki C, Smith JC Jr. Plasma zinc concentration in liver diseases: comparison with normal controls and certain other chronic diseases. Gastroenterology. 1968; 54:1098-1105. [PubMed: 5656329]

50. Walker BE, Dawson JB, Kelleher J, Losowsky MS. Plasma and urinary zinc in patients with malabsorption syndromes or hepatic cirrhosis. Gut. 1973; 14:943-948. [PubMed: 4785284]

51. McClain CJ, Antonow DR, Cohen DA, Shedlofsky S. Zinc metabolism in alcoholic liver disease. Alcohol Clin Exp Res. 1986; 10:582-589. [PubMed: 3544908]

52. Dinsmore W, Callender ME, McMaster D, Todd SJ, Love AH. Zinc absorption in alcoholics using zinc-65. Digestion. 1985; 32:238-242. [PubMed: 4065445]

53. Valberg LS, Flanagan PR, Ghent CN, Chamberlain MJ. Zinc absorption and leukocyte zinc in alcoholic and nonalcoholic cirrhosis. Dig Dis Sci. 1985; 30:329-333. [PubMed: 3979239]

54. Kahn AM, Helwig HL, Redeker AG, Reynolds TB. Urine and serum zinc abnormalities in disease of the liver. Am J Clin Pathol. 1965; 44:426-435. [PubMed: 5839914]

55. Bode JC, Hanisch P, Henning H, Koenig W, Richter F-W, Bode C. Hepatic zinc content in patients with various stages of alcoholic liver disease and in patients with chronic active and chronic persistent hepatitis. Hepatology. 1988; 8:1605-1609. [PubMed: 3192174]

56. Kang YJ, Zhou Z. Zinc prevention and treatment of alcoholic liver disease. Mol Aspects Med. 2005; 26:391-404. [PubMed: 16099027]

57. Kessova I, Cederbaum AI. CYP2E1: biochemistry, toxicology, regulation and function in ethanolinduced liver injury. Curr Mol Med. 2003; 3:509-518. [PubMed: 14527082]

58. Nanji AA, Zhao S, Sadrzadeh SM, Dannenberg AJ, Tahna SR, Waxman DJ. Markedly enhanced cytochrome P450 2E1 induction and lipid peroxidation is associated with severe liver injury in fish-oil-ethanol-fed rats. Alcohol Clin Exp Res. 1994; 18:1280-1285. [PubMed: 7847620]

59. Morgan K, French SW, Morgan TR. Production of a cytochrome P450 2E1 transgenic mouse and initial evaluation of alcoholic liver damage. Hepatology. 2002; 36:122-134. [PubMed: 12085356]

60. Morimoto M, Hagbjork AL, Wan YJ, et al. Modulation of experimental alcohol-induced liver disease by cytochrome P450 2E1 inhibitors. Hepatology. 1995; 21:1610-1617. [PubMed: 7768506] 
61. Das I, Burch RE, Hahn HK. Effects of zinc deficiency on ethanol metabolism and alcohol and aldehyde dehydrogenase activities. J Lab Clin Med. 1984; 104:610-617. [PubMed: 6384394]

62. Zhou Z, Wang L, Song Z, Saari JT, McClain CJ, Kang YJ. Zinc supplementation prevents alcoholic liver disease in mice through attenuation of oxidative stress. Am J Pathol. 2005; 166:1681-1690. [PubMed: 15920153]

63. Hoek JB, Cahill A, Pastorino JG. Alcohol and mitochondria: a dysfunctional relationship. Gastroenterology. 2002; 122:2049-2063. [PubMed: 12055609]

64. Kojima-Yuasa A, Ohkita T, Yukami K, et al. Involvement of intracellular glutathione in zinc deficiency-induced activation of hepatic stellate cells. Chem Biol Interact. 2003; 146:89-99. [PubMed: 12902156]

65. McClain CJ, Song Z, Barve SS, Hill DB, Deaciuc I. Recent advances in alcoholic liver disease, IV: dysregulated cytokine metabolism in alcoholic liver disease. Am J Physiol Gastrointest Liver Physiol. 2004; 287:G497-G502. [PubMed: 15331349]

66. Zhou Z, Wang L, Song Z, Lambert JC, McClain CJ, Kang YJ. A critical involvement of oxidative stress in acute alcohol-induced hepatic TNF-alpha production. Am J Pathol. 2003; 163:1137-1146. [PubMed: 12937155]

67. Lambert JC, Zhou Z, Wang L, Song Z, McClain CJ, Kang YJ. Prevention of alterations in intestinal permeability is involved in zinc inhibition of acute ethanol-induced liver damage in mice. J Pharmacol Exp Ther. 2003; 305:880-886. [PubMed: 12626662]

68. Weismann K, Christensen E, Dreyer V. Zinc supplementation in alcoholic cirrhosis: a double-blind clinical trial. Acta Med Scand. 1979; 205:361-366. [PubMed: 375690]

69. Cesur S, Cebeci SA, Kavas GO, Yilmaz N, Buyukkagnici DI. Serum copper and zinc concentrations in patients with chronic hepatitis C. J Infect. 2005; 51:35-37. [PubMed: 15979488]

70. Cesur S, Cebeci SA, Kavas GO, Aksaray S, Tezeren D. Serum copper and zinc concentrations in patients with chronic hepatitis B. J Infect. 2005; 51:38-40. [PubMed: 15979489]

71. Meram I, Sirmatel F, Ahi S, Tarakcioglu M. Plasma copper and zinc levels in chronic viral hepatitis. Saudi Med J. 2004; 25:1066-1069. [PubMed: 15322599]

72. Loguercio C, De Girolamo V, Federico A, et al. Trace elements and chronic liver diseases. J Trace Elem Med Biol. 1997; 11:158-161. [PubMed: 9442462]

73. Nagamine T, Takagi H, Hashimoto $Y$, et al. The possible role of zinc and metallothionein in the liver on the therapeutic effect of IFN-alpha to hepatits C patients. Biol Trace Elem Res. 1997; 58:65-76. [PubMed: 9363321]

74. Pramoolsinap C, Promvanit N, Komindr S, Lerdverasirikul P, Srianujata S. Serum trace metals in chronic viral hepatitis and hepatocellular carcinoma in Thailand. J Gastroenterol. 1994; 29:610615. [PubMed: 8000510]

75. Takagi H, Nagamine T, Abe T, et al. Zinc supplementation enhances the response to interferon therapy in patients with chronic hepatitis C. J Viral Hepat. 2001; 8:367-371. [PubMed: 11555194]

76. Ko WS, Guo CH, Hsu GSW, Chiou YL, Yeh MS, Yaun SR. The effect of zinc supplementation on the treatment of chronic hepatitis $\mathrm{C}$ patients with interferon and ribavirin. Clin Biochem. 2005; 38:614-620. [PubMed: 15904908]

77. Butterworth RF. The neurobiology of hepatic encephalopathy. Semin Liver Dis. 1996; 16:235244. [PubMed: 8989809]

78. Riggio O, Merli M, Capocaccia L, et al. Zinc supplementation reduces blood ammonia and increases liver ornithine transcarbamylase activity in experimental cirrhosis. Hepatology. 1992; 16:785-789. [PubMed: 1505922]

79. Reding P, Duchateau J, Bataille C. Oral zinc supplementation improves hepatic encephalopathy. Lancet. 1984; 2:493-495. [PubMed: 6147551]

80. Riggio O, Ariosto F, Merli M, et al. Short-term oral zinc supplementation does not improve chronic hepatic encephalopathy: results of a double-blind crossover trial. Dig Dis Sci. 1991; 36:1204-1208. [PubMed: 1893805]

81. Marchesini G, Fabbri A, Bianchi G, Brizi M, Zoli M. Zinc supplementation and amino acidnitrogen metabolism in patients with advanced cirrhosis. Hepatology. 1996; 23:1084-1092. [PubMed: 8621138] 
82. Bresci G, Parisi G, Banti S. Management of hepatic encephalopathy with oral zinc supplementation: a long-term treatment. Eur J Med. 1993; 2:414-416. [PubMed: 8258031]

83. Roberts EA, Schilsky ML. AASLD guideline: a practice guideline on Wilson disease. Hepatology. 2003; 37:1475-1492. [PubMed: 12774027]

84. Brewer GJ, Yuzbasiyan-Gurkan V, Young AB. Treatment of Wilson's disease. Semin Neurol. 1987; 7:209-220. [PubMed: 3332455]

85. Brewer GJ, Hill GM, Prasad AS, Cossack ZT, Rabbani P. Oral zinc therapy for Wilson's disease. Ann Intern Med. 1983; 99:314-319. [PubMed: 6614680]

86. Brewer GJ, Dick RD, Johnson VD, Brunberg JA, Kluin KJ, Fink JK. Treatment of Wilson's disease with zinc, XV: long-term follow-up studies. J Lab Clin Med. 1998; 132:264-278. [PubMed: 9794697]

87. Valta K, Valta P, Hockerstedt K, Lindgren L. Magnesium depletion in chronic terminal liver cirrhosis. Clin Transplant. 2002; 16:325-328. [PubMed: 12225427]

88. Cohen L. Magnesium and liver cirrhosis: a hypothesis. Magnesium. 1985; 4:1-4. [PubMed: 4033201]

89. Patrick L. Nonalcoholic fatty liver disease: relationship to insulin sensitivity and oxidative stress: treatment approaches using vitamin E, magnesium and betaine. Altern Med Rev. 2002; 7:276-291. [PubMed: 12197781]

90. Rosolva H, Mayer O, Reaven G. Effect of variations in plasma magnesium concentration on resistance to insulin-mediated glucose disposal in nondiabetic subjects. J Clin Endocrinol Metab. 1997; 82:3783-3785. [PubMed: 9360541]

91. McNair P, Christiansen C, Madsbad S, et al. Hypomagnesemia, a risk factor in diabetic retinopathy. Diabetes. 1978; 27:1075-1077. [PubMed: 720767]

92. Barbagallo M, Gupta RK, Bardicef M, Resnick LM. Altered ionic effects of insulin in hypertension: role of basal ion levels in determining cellular responsiveness. J Clin Endocrinol Metab. 1997; 82:1761-1765. [PubMed: 9177378]

93. Nadler JL, Buchanan T, Natarajan R, Antonipillai I, Bergman R, Rude R. Magnesium deficiency produces insulin resistance and increased thromboxane synthesis. Hypertension. 1993; 21:10131019.

94. Yajnil CS, Smith RF, Hockaday TD, Ward NI. Fasting plasma magnesium concentrations and glucose disposal in diabetes. BMJ (Clin Res Ed). 1984; 288:1032-1034.

95. Rodriguez-Hernandez H, Gonzalez JL, Rodriguez-Moran M, Guerrero-Romero F. Hypomagnesemia, insulin resistance, and non-alcoholic steatohepatitis in obese subjects. Arch Med Res. 2005; 36:362-366. [PubMed: 15950075]

96. Aagaard NK, Andersen H, Vilstrup H, Clausen T, Jakobsen J, Dorup I. Magnesium supplementation and muscle function in patients with alcoholic liver disease: a randomized, placebo-controlled trial. Scand J Gastroenterol. 2005; 40:972-979. [PubMed: 16173138]

97. Lu SC, Huang ZZ, Yang H, Mato JM, Avila MA, Tsukamoto H. Changes in methionine adenosyltransferase and S-adenosylmethionine homeostasis in alcoholic rat liver. Am J Physiol Gastrointest Liver Physiol. 2000; 279:G178-G185. [PubMed: 10898761]

98. Avila MA, Garcia-Trevijano ER, Martinez-Chantar ML, et al. S-adenosylmethionine revisited: its essential role in the regulation of liver function. Alcohol. 2002; 27:163-167. [PubMed: 12163144]

99. McClain CJ, Hill DB, Song Z, et al. Adenosylmethionine, cytokines, and alcoholic liver disease. Alcohol. 2002; 27:185-192. [PubMed: 12163148]

100. Mato JM, Alvarez L, Ortiz P, Pajares MA. S-adenosylmethionine synthesis: molecular mechanisms and clinical implications. Pharmacol Ther. 1997; 73:265-280. [PubMed: 9175157]

101. Chiang PK, Gordon RK, Tal J, et al. S-adenosylmethionine and methylation. FASEB J. 1996; 10:471-480. [PubMed: 8647346]

102. Hoffman DR, Marion SW, Cornatzer WE, Duerre JA. S-adenosylmethionine and Sadenosylhomocysteine metabolism in isolated rat liver: effects of L-methionine, L-homocysteine, and adenosine. J Biol Chem. 1980; 255:10822-10827. [PubMed: 7430157]

103. Horowitz JH, Rypins EB, Henderson JM, et al. Evidence for impairment of transsulfuration pathway in cirrhosis. Gastroenterology. 1981; 81:668-675. [PubMed: 7262512] 
104. Cabrero C, Duce AM, Ortiz P, Alemany S, Mato JM. Specific loss of high molecular weight form of S-adenosyl-L-methionine synthetase in human liver cirrhosis. Hepatology. 1988; 8:1530 1534. [PubMed: 3192166]

105. Corrales F, Gimenez A, Alvarez L, et al. S-adenosylmethionine treatment prevents carbon tetrachloride-induced S-adenosylmethionine synthetase inactivation and attenuates liver injury. Hepatology. 1992; 16:1022-1027. [PubMed: 1398482]

106. Varela-Moreiras G, Alonso-Aperte E, Rubio M, et al. Carbon tetrachloride-induced hepatic injury is associated with global DNA hypomethylation and homocysteinemia: effect of Sadenosylmethionine treatment. Hepatology. 1995; 22:1310-1315. [PubMed: 7557886]

107. Song Z, Zhou Z, Chen T, et al. S-adenosylmethionine (SAMe) protects against acute alcohol induced hepatotoxicity in mice. J Nutr Biochem. 2003; 14:591-597. [PubMed: 14559110]

108. Chawla RK, Lewis FW, Kutner MH, Bate DM, Roy RG, Rudman D. Plasma cysteine, cystine, and glutathione in cirrhosis. Gastroenterology. 1984; 87:770-776. [PubMed: 6468868]

109. Lieber CS, Casine A, De Carli LM, Lowe N, Sasaki R, Leo MA. S-adenosyl-L-methionine attenuates alcohol-induced liver injury in the baboon. Hepatology. 1990; 11:165-172. [PubMed: 2307395]

110. Sanchez-Gongora E, Ruiz F, Mingorance J, An W, Corrales FJ, Mato JM. Interaction of liver methionine adenosyltransferase with hydroxyl radical. FASEB J. 1997; 11:1013-1019. [PubMed: 9337154]

111. Hirano T, Kaplowitz N, Tsukamoto H, Kamimura S, Fernandez-Checa JC. Hepatic mitochondrial glutathione depletion and progression of experimental alcoholic liver disease in rats. Hepatology. 1992; 16:1423-1427. [PubMed: 1446896]

112. Loguercio C, Nardi G, Argenzio F, et al. Effect of S-adenosyl-L-methionine administration on red blood cell cysteine and glutathione levels in alcoholic patients with and without liver disease. Alcohol Alcohol. 1994; 29:597-604. [PubMed: 7811344]

113. Frezza M, Surrenti C, Manzillo G, Fiaccadori F, Bortolini M, Di Padova C. Oral Sadenosylmethionine in the symptomatic treatment of intrahepatic cholestasis: a double-blind, placebo-controlled study. Gastroenterology. 1990; 99:211-215. [PubMed: 2188871]

114. Nicastri PL, Diaferia A, Tartagni M, Loizzi P, Fanelli M. A randomised placebo-controlled trial of ursodeoxycholic acid and S-adenosylmethionine in the treatment of intrahepatic cholestasis of pregnancy. Br J Obstet Gynaecol. 1998; 105:1205-1207. [PubMed: 9853771]

115. Frezza M, Centini G, Cammareri G, Le Grazie C, Di Padova C. S-adenosylmethionine for the treatment of intrahepatic cholestasis of pregnancy: results of a controlled clinical trial. Hepatogastroenterology. 1990; 2:122-125. [PubMed: 2083923]

116. Mato JM, Camara J, Fernandez de Paz J, et al. S-adenosylmethionine in alcoholic liver cirrhosis: a randomized, placebo-controlled, double-blind, multicenter clinical trial. J Hepatol. 1999; 30:1081-1089. [PubMed: 10406187]

117. Craig SA. Betaine in human nutrition. Am J Clin Nutr. 2004; 80:539-549. [PubMed: 15321791]

118. Song Z, Zhou Z, Uriarte S, et al. S-adenosylhomocysteine sensitizes to TNF-alpha hepatotoxicity in mice and liver cells: a possible etiological factor in alcoholic liver disease. Hepatology. 2004; 40:989-997. [PubMed: 15382170]

119. Kim SK, Kim YC, Kim YC. Effects of singly administered betaine on hepatotoxicity of chloroform in mice. Food Chem Toxicol. 1998; 36:655-661. [PubMed: 9734716]

120. Kim SK, Kim YC. Attenuation of bacterial lipopolysaccharide-induced hepatotoxicity by betaine or taurine in rats. Food Chem Toxicol. 2002; 40:545-549. [PubMed: 11893413]

121. Junnila M, Barak AJ, Beckenhauer HC, Rahko T. Betaine reduces hepatic lipidosis induced by carbon tetrachloride in Sprague-Dawley rats. Vet Hum Toxicol. 1998; 40:263-266. [PubMed: 9778759]

122. Ji C, Kaplowitz N. Betaine decreases hyperhomocysteinemia, endoplasmic reticulum stress, and liver injury in alcohol-fed mice. Gastroenterology. 2003; 124:1488-1499. [PubMed: 12730887]

123. Barak AJ, Beckenhauer HC, Mailliard ME, Kharbanda KK, Tuma DJ. Betaine lowers elevated sadenosylhomocysteine levels in hepatocytes from ethanol-fed rats. J Nutr. 2003; 133:2845-2848. [PubMed: 12949375] 
124. Lieber CS, Robins SJ, Leo MA. Hepatic phosphatidylethanolamine methyltransferase activity is decreased by ethanol and increased by phosphatidylcholine. Alcohol Clin Exp Res. 1994; 18:592-595. [PubMed: 7943660]

125. Lee TD, Sadda MR, Mendler MH, Bottiglieri T, Kanel G, Mato JM, Lu SC. Abnormal hepatic methionine and glutathione metabolism in patients with alcoholic hepatitis. Alcohol Clin Exp Res. 2004; 28:173-181. [PubMed: 14745316]

126. Attwood JT, Yung RL, Richardson BC. DNA methylation and the regulation of gene transcription. Cell Mol Life Sci. 2002; 59:241-257. [PubMed: 11915942]

127. Antequera F. Structure, function and evolution of CpG island promoters. Cell Mol Life Sci. 2003; 60:1647-1658. [PubMed: 14504655]

128. McBride AE, Silver PA. State of the arg: protein methylation at arginine comes of age. Cell. 2001; 106:5-8. [PubMed: 11461695]

129. Fulda S, Kufer MU, Meyer E, van Valen F, Dockhorn-Dworniczak B, Debatin KM. Sensitization for death receptor- or drug-induced apoptosis by re-expression of caspase- 8 through demethylation or gene transfer. Oncogene. 2001; 20:5865-5877. [PubMed: 11593392]

130. Hopkins-Donaldson S, Ziegler A, Kurtz S, et al. Silencing of death receptor and caspase-8 expression in small cell lung carcinoma cell lines and tumors by DNA methylation. Cell Death Differ. 2003; 10:356-364. [PubMed: 12700635]

131. Zhu X, Song J, Mar MH, Edwards LJ, Zeisel SH. Phosphatidylethanolamine N-methyltransferase (PEMT) knockout mice have hepatic steatosis and abnormal hepatic choline metabolite concentrations despite ingesting a recommended dietary intake of choline. Biochem J. 2003; 370(pt 3):987-993. [PubMed: 12466019]

132. Abdelmalek MF, Angulo P, Jorgensen RA, Sylvestre PB, Lindor KD. Betaine, a promising new agent for patients with nonalcoholic steatohepatitis: results of a pilot study. Am J Gastroenterol. 2001; 96:2711-2717. [PubMed: 11569700]

133. Luper S. A review of plants used in the treatment of liver disease: part 1. Altern Med Rev. 1998; 3:410-421. [PubMed: 9855566]

134. Flora K, Hahn M, Rosen H, Benner K. Milk thistle (Silybum marianum) for the therapy of liver disease. Am J Gastroenterol. 1998; 93:139. [PubMed: 9468229]

135. Vogel G, Tuchweber B, Trost W, Mengs U. Protection by silibinin against Amanita phalloides intoxication in beagles. Toxicol Appl Pharmacol. 1984; 73:355. [PubMed: 6719456]

136. Ferenci P, Dragosies B, Dittrich H, Le Grazie C, Di Padova C. Randomized controlled trial of silymarin treatment in patients with cirrhosis of the liver. J Hepatol. 1989; 9:105. [PubMed: 2671116]

137. Mira ML, Azevedo MS, Manso C. The neutralization of hydroxyl radical by silibin, sorbinil and bendazac. Free Radic Res Commun. 1987; 4:125-129. [PubMed: 3508133]

138. Mira L, Silva M, Manso CF. Scavenging of reactive oxygen species by silibinin dihemisuccinate. Biochem Pharmacol. 1994; 48:753-759. [PubMed: 8080448]

139. Valenzuela A, Aspillaga M, Vial S, Guerra R. Selectivity of silymarin on the increase of the glutathione content in different tissues of the rat. Planta Med. 1989; 55:420-422. [PubMed: 2813578]

140. Muzes G, Deak G, Lang I, Nekam K, Gergely P, Feher J. Effect of the biflavonoid silymarin on the in vitro activity and expression of superoxide dismutase (SOD) enzyme. Acta Physiol Hung. 1991; 78:3-9. [PubMed: 1763650]

141. Varga Z, Czompa A, Kakuk G, Antus S. Inhibition of the superoxide anion release and hydrogen peroxide formation in PMNLs by flavonolignans. Phytother Res. 2001; 15:608-612. [PubMed: 11746843]

142. Saliou C, Rihn B, Cillard J, Okamoto T, Packer L. Selective inhibition of NF-kappaB activation by the flavonoid hepatoprotector silymarin in HepG2: evidence for different activating pathways. FEBS Lett. 1998; 440:8-12. [PubMed: 9862414]

143. Schumann N, Prockl J, Kiemer AK, Vollmar AM, Bang R, Tiegs G. Silibinin protects mice from T-cell dependent liver injury. J Hepatol. 2003; 39:333-340. [PubMed: 12927918] 
144. Bosisio E, Benelli C, Pirola O. Effect of the flavonolignans of Silybum marianum L. on lipid peroxidation in rat liver micro-somes and freshly isolated hepatocytes. Pharmacol Res. 1992; 25:147-154. [PubMed: 1635893]

145. Schriever H, Kramer U, Rutkowski G, Borgis KJ. Influence of silibin dihemisuccinate on fatty acid synthesis in rat liver. Arzneimittelforschung. 1979; 29:524-526. [PubMed: 39576]

146. van Pelt JF, Verslype C, Crabbe T, Zaman Z, Fevery J. Primary human hepatocytes are protected against prolonged and repeated exposure to ethanol by silibinin-dihemisuccinate. Alcohol Alcohol. 2003; 38:411-414. [PubMed: 12915515]

147. Lieber CS, Leo MA, Cao Q, DeCarli LM. Silymarin retards the progression of alcohol-induced hepatic fibrosis in baboons. J Clin Gastroenterol. 2003; 37:336-339. [PubMed: 14506392]

148. Fuchs EC, Weyhenmeyer R, Weiner OH. Effects of silibinin and of a synthetic analoge on isolated rat hepatic stellate cell and myofibroblasts. Arzneimittelforschung. 1997; 47:1383-1387. [PubMed: 9450168]

149. Magliulo E, Carosi PG, Minoli L, Gorini S. Studies on the regenerative capacity of the liver in rats subjected to partial hepatectomy and treated with silymarin. Arzneimittelforschung. 1973; 23(suppl):161-167. [PubMed: 4740690]

150. Pares A, Planas R, Torres M, et al. Effects of silymarin in alcoholic patients with cirrhosis of the liver: results of a controlled, double-blind, randomized and multicenter trial. J Hepatol. 1998; 28:615-621. [PubMed: 9566830]

151. Velussi M, Cernigoi AM, De Monte A, Dapas F, Caffau C, Zilli M. Long-term (12 months) treatment with an anti-oxidant drug (silymarin) is effective on hyperinsulinemia, exogenous insulin need and malondialdehyde levels in cirrhotic diabetic patients. J Hepatol. 1997; 26:871879. [PubMed: 9126802]

152. Levy C, Seeff LD, Lindor KD. Use of herbal supplements for chronic liver disease. Clin Gastroenterol Hepatol. 2004; 2:947-956. [PubMed: 15551246]

153. Yoshikawa M, Matsui Y, Kawamoto H, et al. Effects of glycyrrhizin on immune-mediated cytotoxicity. J Gastroenterol Hepatol. 1997; 12:243-248. [PubMed: 9142643]

154. Shiki Y, Ishikawa Y, Shirai K, Saito Y, Yoshida S. Effect of glycyrrhizin on lysosomes labilization by phospholipase A2. Am J Chin Med. 1986; 14:131-137. [PubMed: 3799529]

155. Shiki Y, Shirai K, Saito Y, Yoshida S, Mori Y, Wakashin M. Effect of glycyrrhizin on lysis of hepatocytes membranes induced by anti-liver cell membrane antibody. J Gastroenterol Hepatol. 1992; 7:12-16. [PubMed: 1543863]

156. Crance JM, Leveque F, Biziagos E, van Cuyck-Gandre H, Jouan A, Deloince R. Studies on mechanism of action of glycyrrhizin against hepatitis A virus replication in vitro. Antiviral Res. 1994; 23:63-76. [PubMed: 8141593]

157. van Rossum TG, Vulto AG, de Man RA, Brouwer JT, Schalm SW. Review article: glycyrrhizin as a potential treatment for chronic hepatitis C. Aliment Pharmacol Ther. 1998; 12:199-205. [PubMed: 9570253]

158. Okamoto T. The protective effect of glycyyrhizin on anti-Fas antibody-induced hepatitis in mice. Eur J Pharmacol. 2000; 387:229-232. [PubMed: 10650164]

159. Jeong HG, You HO, Park SJ, et al. Hepatoprotective effects of $18 \beta$-glycyrrhetinic acid on carbon tetrachloride-induced liver injury: inhibition of cytochrome P450 2E1 expression. Pharmacol Res. 2002; 46:221-227. [PubMed: 12220964]

160. Abe N, Ebina T, Ishida N. Interferon induction by glycyrrhizin and glycyrrhetinic acid in mice. Microbiol Immunol. 1982; 26:535-539. [PubMed: 6290851]

161. Abe M, Akbar SKMD, Hasebe A, Horiike N, Onji M. Glycyrrhizin enhances interleukin-10 production by liver dendritic cells in mice with hepatitis. J Gastroenterol. 2003; 38:962-967. [PubMed: 14614603]

162. Suzuki H, Ohta Y, Takino T, Fujisawa K, Hirayama C. Effects of glycyrrhizin on biochemical tests in patients with chronic hepatitis. Asian Med J. 1983; 26:423-438.

163. Arase Y, Ikeda K, Murashima N, et al. The long term efficacy of glycyrrhizin in chronic hepatitis C patients. Cancer. 1997; 79:1494-1500. [PubMed: 9118029] 
164. Kiyosawa K, Sodeyama T, Tanaka E, et al. Interrelationship of blood transfusion, non-A, non-B hepatitis and hepatocellular carcinoma: analysis by detection of antibody to hepatitis $\mathrm{C}$ virus. Hepatology. 1990; 12:671-675. [PubMed: 2170265]

165. Tarao K, Takemiya S, Tamai S, et al. Relationship between the recurrence of hepatocellular carcinoma (HCC) and serum ala-nine aminotransaminase levels in hepatectomized patients with hepatitis C virus-associated cirrhosis and HCC. Cancer. 1997; 79:688-694. [PubMed: 9024706]

166. Miyake K, Tango T, Ota Y, et al. Efficacy of Stronger Neo-Minophagen C compared between two doses administered three times a week on patients with chronic viral hepatitis. J Gastroenterol Hepatol. 2002; 17:1198-1204. [PubMed: 12453280]

167. Fujiyama S, Chikazawa H, Honda Y, et al. Treatment of chronic active hepatitis $\mathrm{C}$ with interferon-alpha $2 \mathrm{~b}$-alone and in combi nation with Stronger Neo Minophagen C. Biother Jpn. 1998; 12:1495-1513.

168. Suzuki Y, Ikeda K, Saitoh S, et al. A prospective randomized administration of Stronger Neo Minophagen $\mathrm{C}$ as an adjuvant therapy for chronic hepatitis type $\mathrm{C}$ treated with interferon. Acta Hepatol Jpn. 1996; 37:363-367.

169. Stewart PM, Wallace AM, Valentino R, Burt D, Shackleton CH, Edwards CR. Mineralocorticoid activity of liquorice: 11-beta-hydroxysteroid dehydrogenase deficiency comes of age. Lancet. 1987; 2:821-824. [PubMed: 2889032]

170. Van Rossum TG, De Jong FH, Hop WC, Boomsma F, Schalm SW. Chronic hepatitis C and portal hypertension: diagnosis, treatment with interferon, glycyrrhizin or propanolol: "pseudoaldosteronism" induced by intravenous glycyrrhizin treatment of chronic hepatitis C patients. J Gastroenterol Hepatol. 2001; 16:789-795. [PubMed: 11446888]

171. Heck AM, DeWitt BA, Lukes AL. Potential interactions between alternative therapies and warfarin. Am J Health Syst Pharm. 2000; 57:1221-1227. [PubMed: 10902065]

172. Shimizu I, Ma YR, Mizobuchi Y, et al. Effects of Sho-saiko-to, a Japanese herbal medicine, on hepatic fibrosis in rats. Hepatology. 1999; 29:149-160. [PubMed: 9862861]

173. Yamashiki M, Nishimura A, Suzuki H, Sakaguchi S, Kosaka Y. Effects of the Japanese herbal medicine "Sho-saiko-to" (TJ-9) on in vitro interleukin-10 production by peripheral blood mononu-clear cells of patients with chronic hepatitis C. Hepatology. 1997; 25:1390-1397. [PubMed: 9185758]

174. Oka H, Yamamoto S, Kuroki T, et al. Prospective study of chemoprevention of hepatocellular carcinoma with Sho-saiko-to (TJ-9). Cancer. 1995; 75:743-749. [PubMed: 8625175]

175. Hirayama C, Okumura M, Tanikawa K, Yano M, Mizuta M, Ogawa N. A multicenter randomized controlled clinical trial of Sho-saiko-to in chronic active hepatitis. Gastroenterol Jpn. 1989; 24:715-719. [PubMed: 2691317]

176. Katou K, Mori K. Autoimmune hepatitis with drug-induced pneumonia due to Sho-saiko-to. Nihon Kokyuki Gakkai Zasshi. [Jpn J Thorac Dis]. 1999; 37:641-646.

177. Murakami K, Okajima K, Sakata K, Takatsuki K. A possible mechanism of interstitial pneumonia during interferon therapy with sho-saiko-to. Nihon Kyobu Shikkan Gakkai Zasshi [Jpn J Thorac Dis]. 1995; 33:389-394.

178. Liu J, Lin H, McIntosh H. Genus Phyllanthus for chronic hepatitis B virus infection: a systematic review. J Viral Hepatol. 2001; 8:358-366.

179. Lee CD, Ott M, Thyagarajan SP, Shafritz DA, Burk RD, Gupta S. Phyllanthus amarus downregulates hepatitis B virus mRNA transcription and replication. Eur J Clin Invest. 1996; 26:1069-1076. [PubMed: 9013081]

180. Chan HLY, Sung JJY, Fong AML, et al. Double-blinded placebo-controlled study of Phyllanthus urinaris for the treatment of chronic hepatitis B. Aliment Pharmacol Ther. 2003; 18:339-345. [PubMed: 12895219]

181. Vaidya AB, Antarkar DS, Doshi JC, et al. Picrorrhiza kurroa (Kutaki) Royle ex Benth as a hepatoprotective agent: experimental and clinical studies. J Postgrad Med. 1996; 42:105-108. [PubMed: 9715310]

182. Ansari RA, Tripathi SC, Patnaik GK, Dhawan BN. Antihepatotoxic properties of picroliv: an active fraction from rhizomes of Picrorrhiza kurroa. J Ethnopharmacol. 1991; 34:61-68. [PubMed: 1753788] 
183. Batey R, Cao Q, Pang G, Clancy RL. Effects of CH-100, a Chinese herbal medicine, on acute concanavalin A-mediated hepatitis in control and alcohol-fed rats. Alcohol Clin Exp Res. 2000; 24:852-858. [PubMed: 10888074]

184. Batey RG, Bensoussan A, Fan YY, Bollipo S, Hossain MA. Preliminary report of a randomized, double-blinded placebo-controlled trial of a Chinese herbal medicine preparation $\mathrm{CH}-100$ in the treatment of chronic hepatitis C. J Gastroenterol Hepatol. 1998; 13:244-247. [PubMed: 9570235]

185. Wang L, Wnag BE, Xiao PG, Qiao YJ, Tan XH. Effects of herbal compound 861 on human hepatic stellate cell proliferation and activation. World J Gastroenterol. 2004; 10:2831-2835. [PubMed: 15334680]

186. Jia JD, Wang BE, Dong Z, Cui L, Zhu JX, Che JT. The effect of herbal compound 861on mRNA levels for type I, III, and IV collagens and TGF in immune complex rat liver fibrosis. Chin J Hepatol. 1996; 4:214-216.

187. Yin SS, Wang BE, Wang TL, Jia JD, Qian LX. The effect of Cpd 861 on chronic hepatitis B related fibrosis and early cirrhosis: a randomized, double blind, placebo controlled clinical trial. Zhonghua Gan Zang Bing Za Zhi. 2004; 12:467-470. [PubMed: 15329205]

188. Yang F, de Villiers WJS, McClain CJ, Varilek GW. Green tea polyphenols block endotoxininduced tumor necrosis factor- $\alpha$ production and lethality in a murine model. J Nutr. 1998; 128:2334-2340. [PubMed: 9868178]

189. Fiorini RN, Donovan JL, Rodwell D, et al. Short-term administration of (-)-epigallocatechin gallate reduces hepatic steatosis and protects against warm hepatic ischemia/reperfusion injury in steatotic mice. Liver Transplant. 2005; 11:298-308.

190. Sakata R, Ueno T, Nakamura T, Sakamoto M, Torimura T, Sata M. Green tea polyphenol epigallocatechin-3-gallate inhibits platelet-derived growth factor-induced proliferation of human hepatic stellate cell line LI90. J Hepatol. 2004; 40:52-59. [PubMed: 14672614]

191. Lin CF, Wong KL, Wu RC, Huang TC, Liu CF. Protection by hot water extract of Panax notoginseng on chronic ethanol-induced hepatotoxicity. Phytother Res. 2003; 17:1119-1122. [PubMed: 14595601]

192. Park WH, Lee SK, Kim CH. A Korean herbal medicine, Panax notoginseng, prevents liver fibrosis and hepatic microvascular dysfunction in rats. Life Sci. 2005; 76:1675-1690. [PubMed: 15698847]

193. Clouatre DL. Kava kava: examining new reports of toxicity. Toxicol Lett. 2004; 150:85-96. [PubMed: 15068826]

194. Levi M, Guchelaar HJ, Woerdenbag, Zhu YP. Acute hepatitis in a patient using a Chinese herbal tea: a case report. Pharmacy World Sci. 1998; 20:43-44.

195. Kao WF, Hung DZ, Tsai WJ, Lin KP, Deng JF. Podophyllotoxin intoxication: toxic effects of bajiaolian in herbal therapeutics. Hum Exp Toxicol. 1992; 11:480-487. [PubMed: 1361136]

196. Whiting PW, Clouston A, Kerlin P. Black cohosh and other herbal remedies associated with acute hepatitis. Med J Aust. 2002; 177:440-443. [PubMed: 12381254]

197. Nadir A, Reddy D, Van Thiel DH. Cascara sagrada-induced intrahepatic cholestasis causing portal hypertension: case report and review of herbal hepatotoxicity. Am J Gastroenterol. 2000; 95:3634-3637. [PubMed: 11151906]

198. Benninger J, Schneider HT, Schuppan D, Kirchner T, Hahn EG. Acute hepatitis induced by greater celandine (Chelidonium majus). Gastroenterology. 1999; 117:1234-1237. [PubMed: 10535888]

199. Sheikh NM, Philen RM, Love LA. Chaparral-associated hepatotoxicity. Arch Intern Med. 1997; 157:913-919. [PubMed: 9129552]

200. Grant KL, Boyer LV, Erdman BE. Chaparral-induced hepatotoxicity. Integrative Med. 1998; 1:83-87.

201. Vautier G, Spiller RC. Safety of complementary medicines should be monitored. BMJ. 1995; 311:633. [PubMed: 7663283]

202. Castot A, Larrey D. Acute hepatitis following administration of germander-containing products: 26 cases. Gastroenterol Clin Biol. 1992; 16:916-922. [PubMed: 1493896]

203. Willett KL, Roth RA, Walker L. Workshop overview: hepatotoxicity assessment for botanical dietary supplements. Toxicol Sci. 2004; 79:4-9. [PubMed: 14976355] 
204. Nadir A, Agrawal S, King PD, Marshall JB. Acute hepatitis associated with the use of a Chinese herbal product ma-huang. Am J Gastroenterol. 1996; 91:1436-1438. [PubMed: 8678010]

205. Anderson IB, Mullen WH, Meeker JE, et al. Pennyroyal toxicity measurement of toxic metabolite levels in two cases and review of the literature. Ann Intern Med. 1996; 124:726-734. [PubMed: 8633832]

206. Pearson W. Pyrrolizidine alkaloids in higher plants: hepatic veno-occlusive disease associated with chronic consumption. J Neutraceuticals. 2000; 3:87-96.

207. Angell M, Kassirer JP. Alternative medicine: the risks of untested and unregulated remedies. N Engl J Med. 1998; 339:839. [PubMed: 9738094]

208. Ko RJ. Adulterants in Asian patent medicines. N Engl J Med. 1998; 339:847. [PubMed: 9750079]

209. Ruschitzka F, Meier PJ, Turina M, Luscher TF, Noll G. Acute heart transplant rejection due to Saint John's wort. Lancet. 2000; 355:548. [PubMed: 10683008]

210. Piscitelli SC, Burstein AH, Chaitt D, Alfaro RM, Falloon J. Indinavir concentrations and St. John's wort. Lancet. 2000; 355:547-548. [PubMed: 10683007] Lancet. 2001; 357:1210. Erratum in.

211. Brewer GJ. Zinc acetate for the treatment of Wilson's disease. Expert Opin Pharmacother. 2001; 2:1473-1477. [PubMed: 11585025]

212. Miller ER 3rd, Pastor-Barriuso R, Dalal D, Riemersma RA, Appel LJ, Guallar E. Meta-analysis: high-dosage vitamin E supplementation may increase all-cause mortality. Ann Intern Med. 2005; 142:37-46. [PubMed: 15537682] 


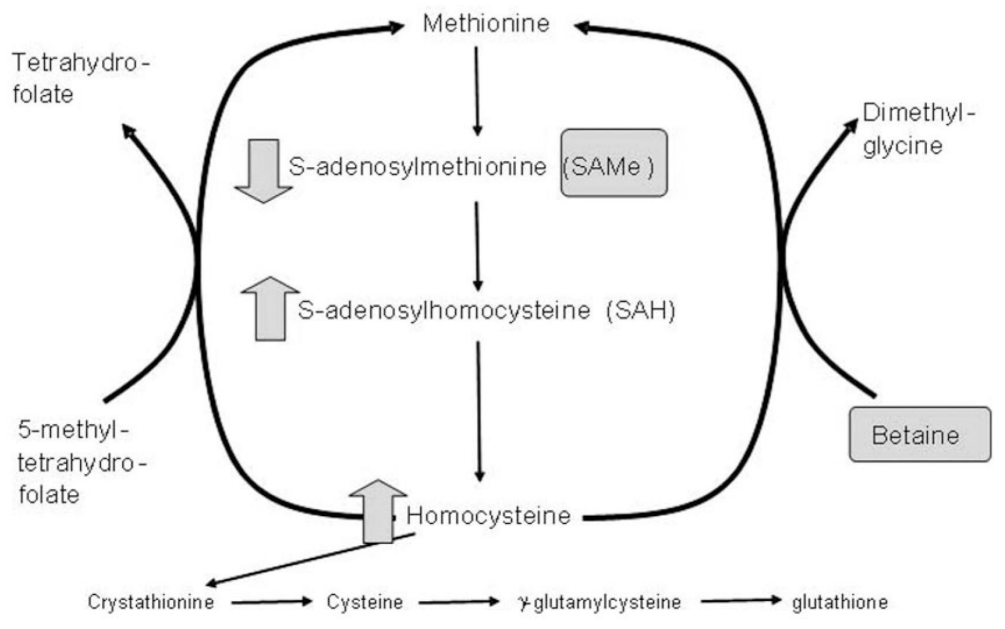

Figure 1.

Betaine facilitates methionine regeneration from homocysteine. 
Table 1

Selected other CAM therapy in liver disease

\begin{tabular}{|c|c|}
\hline Agent and references & Description \\
\hline TJ-9 ${ }^{172-177}$ & $\begin{array}{l}\text { TJ-9 consists of } 7 \text { different herbs and has been used extensively in China and Japan. } \\
\text { There are multiple potential mechanisms of action, including decreasing stellate cell } \\
\text { activation, decreasing TGF beta and platelet-derived growth factor (PDGF), and } \\
\text { decreasing hepatic fibrogenesis. It also can act as an antioxidant and can increase } \\
\text { IL-10. It has been used in clinical trials with some benefit in hepatic fibrosis; } \\
\text { however, there are some safety issues, including pulmonary fibrosis. }\end{array}$ \\
\hline Phyllanthus amarus $178-180$ & $\begin{array}{l}\text { Phyllanthus amarus has been used mainly to treat hepatitis B. Some studies have } \\
\text { suggested that this agent is as effective as interferon at clearing hepatitis B virus or } \\
\text { may act in concert with interferon in clearing the hepatitis B virus, but these data } \\
\text { are controversial. }\end{array}$ \\
\hline Picrorrhiza kurroa ${ }^{181,182}$ & $\begin{array}{l}\text { Picrorrhiza kurroa is an herb from northwest India that protects against a variety of } \\
\text { hepatotoxins, such as galactosamine, alcohol, carbon tetrachloride, aflatoxin. The } \\
\text { clinical utility of this drug is not well documented. }\end{array}$ \\
\hline $\mathrm{CH}-100^{183,184}$ & $\begin{array}{l}\mathrm{CH}-100 \text { is a blend of } 19 \text { different herbs used in China to treat liver disease. It has } \\
\text { immunomodulatory and anti-inflammatory effects. }\end{array}$ \\
\hline Compound $861^{185-187}$ & $\begin{array}{l}\text { Compound } 861 \text { is a traditional Chinese medicine. It is an extract from } 10 \text { different } \\
\text { herbs. It has fairly prominent antifibrotic activities. It decreases stellate cell } \\
\text { activation in vitro and fibrogenesis in vivo in experimental animals. It has been } \\
\text { used extensively in the treatment of chronic hepatitis B in Asia, with generally } \\
\text { positive effects on hepatic fibrosis. }\end{array}$ \\
\hline Green tea polyphenols ${ }^{188-190}$ & $\begin{array}{l}\text { They have prominent antioxidant and anti-inflammatory properties, block endotoxin } \\
\text { lethality, endotoxin-stimulated TNF production, and NFkB activation in experimental } \\
\text { animals. They also block experimental ischemia/reperfusion and stellate cell } \\
\text { activation, but there are few human data. }\end{array}$ \\
\hline Ginseng 191,192 & $\begin{array}{l}\text { Panax notoginseng (PNG) has been used in Chinese medicine for centuries, and it } \\
\text { has hepatoprotective effects in experimental animals. It has been shown to } \\
\text { decrease oxidative stress, lipid peroxidation, TNF production, and stellate cell } \\
\text { activation. There is limited human information in liver disease. }\end{array}$ \\
\hline
\end{tabular}

TGF, tumor growth factor; TNF, tumor necrosis factor. 
Table 2

\section{Selected CAM agents and related hepatotoxicity}

\begin{tabular}{|c|c|}
\hline $\begin{array}{l}\text { Herb/supplement and } \\
\text { references }\end{array}$ & Action \\
\hline Aristolochia ${ }^{194}$ & $\begin{array}{l}\text { The root of Aristolochia debilis contains the highly toxic aristolochic acid, which caused hepatitis in } \\
\text { a woman whose tea contained the herb. Liver function improved after about } 3 \text { months. }\end{array}$ \\
\hline Bajiaolian $^{195}$ & $\begin{array}{l}\text { Bajiaolian has been used in treatment of tumors and snakebites. However, several patients } \\
\text { developed abdominal pain, as well as elevation of their liver enzymes within } 2 \text { hours of ingestion. }\end{array}$ \\
\hline Black cohosh ${ }^{196}$ & $\begin{array}{l}\text { Black cohosh is a popular herbal remedy used for treatment of menopausal symptoms. However, } \\
\text { there are multiple reports of hepatotoxicity, including fulminant hepatic failure. }\end{array}$ \\
\hline Cascara sagrada ${ }^{197}$ & $\begin{array}{l}\text { Cascara is a tree native to North America, and its extracts from dried bark are used as stimulatory } \\
\text { laxatives. A man developed cholestatic hepatitis, as well as portal hypertension. After stopping the } \\
\text { laxative, his symptoms improved over time. }\end{array}$ \\
\hline Celandine ${ }^{198}$ & $\begin{array}{l}\text { Celandine can cause acute hepatitis. Approximately } 10 \text { cases were seen within a } 2 \text {-year period in a } \\
\text { German hospital, and all patients recovered within } 6 \text { months. }\end{array}$ \\
\hline Chaparral ${ }^{199,200}$ & $\begin{array}{l}\text { Chaparral is an herb used especially for respiratory tract infections. Liver damage had been } \\
\text { associated with using this herb; however, liver function improved after cessation of this agent. }\end{array}$ \\
\hline Eternal life 201 & A Chinese herbal remedy called "eternal life" has been associated with 2 cases of hepatotoxicity. \\
\hline Germander 202 & $\begin{array}{l}\text { Germander has been used for nearly } 2 \text { millennia for the treatment of fevers and abdominal } \\
\text { disorders. In 1986, germander was marketed to treat obesity, and up to } 30 \text { cases of acute } \\
\text { hepatitis were reported in France. This association with liver damage caused products containing } \\
\text { the herb to be removed from the market. Previously used for its antimicrobial and anti-inflammatory } \\
\text { activity, some cases did cause severe liver damage. Some animal models showed that germander } \\
\text { formed active metabolites that depleted glutathione stores and caused apoptosis. }\end{array}$ \\
\hline Kava kava ${ }^{193}$ & $\begin{array}{l}\text { Kava has been documented to have caused hundreds of cases of hepatic damage worldwide. } \\
\text { Symptoms usually occurred after about } 3-16 \text { weeks of kava use, leading to various liver toxicities, } \\
\text { ranging from transient liver enzyme elevations to fulminant liver failure. Three proposed } \\
\text { mechanisms of hepatotoxicity include inhibition of cytochrome P450, reduction of liver glutathione } \\
\text { stores, and inhibition of cyclooxygenase activity. }\end{array}$ \\
\hline LipoKinetix $^{203}$ & $\begin{array}{l}\text { A dietary supplement used for weight loss, LipoKinetix has caused acute hepatitis and fulminant } \\
\text { hepatic failure. }\end{array}$ \\
\hline Ma huang 204 & $\begin{array}{l}\text { Ma huang, or ephedra, has been used in weight loss and increasing energy. It has been implicated } \\
\text { in acute hepatitis, as well as its more common side effects. }\end{array}$ \\
\hline Pennyroyal 205 & $\begin{array}{l}\text { Pennyroyal, or Mentha pulegium, use has been associated with severe hepatotoxicity, including } 1 \\
\text { fatality. }\end{array}$ \\
\hline $\begin{array}{l}\text { Pyrrolizidine } \\
\text { alkaloids }^{206}\end{array}$ & $\begin{array}{l}\text { Pyrrolizidine or mixtures containing this herbal ingredient have been reported to induce portal } \\
\text { hypertension, ascites, and eventual hepatic failure. This herbal constituent has been found to cause } \\
\text { veno-occlusive disease, leading to the above problems, and has also been associated with severe } \\
\text { hepatitis and hepatocellular carcinoma. }\end{array}$ \\
\hline Senna ${ }^{201}$ & $\begin{array}{l}\text { A very common herbal used in Western medicine as a laxative, senna has been reported to cause } \\
\text { toxic hepatitis after overdosing. }\end{array}$ \\
\hline Skullcap ${ }^{196}$ & $\begin{array}{l}\text { Scutellaria lateriflora, or skullcap, has been reported to cause veno-occlusive disease and liver } \\
\text { failure. }\end{array}$ \\
\hline
\end{tabular}

Nutr Clin Pract. Author manuscript; available in PMC 2014 November 21. 